Elsevier required licence: (C) <2018>. This manuscript version is made available under the CC-BY-NC-ND 4.0 license http://creativecommons.org/licenses/by-nc-nd/4.0/ 


\title{
Characteristics and mechanisms of cadmium adsorption onto biogenic aragonite shells-derived biosorbent: Batch and column studies
}

\author{
Huu Tap Van ${ }^{1}$, Lan Huong Nguyen ${ }^{2}$, Van Dang Nguyen ${ }^{3}$, Xuan Hoan Nguyen ${ }^{2}$, Thanh Hai \\ Nguyen $^{4}$, Tien Vinh Nguyen ${ }^{5}$, Saravanamuth Vigneswaran ${ }^{5}$, Jörg Rinklebe ${ }^{6,7}$, Hai Nguyen Tran ${ }^{8^{*}}$ \\ ${ }^{1}$ Faculty of Natural Resources and Environment, Thai Nguyen University of Sciences (TNUS), Tan \\ Thinh ward, Thai Nguyen city, Vietnam. \\ ${ }^{2}$ Faculty of Environment - Natural Resources and Climate Change, Ho Chi Minh City University of \\ Food Industry (HUFI), 140 Le Trong Tan Street, Tay Thanh Ward, Tan Phu District, Ho Chi Minh \\ City, Vietnam. \\ ${ }^{3}$ Faculty of Physic and Technology, Thai Nguyen University of Sciences (TNUS), Tan Thinh ward, \\ Thai Nguyen city, Vietnam. \\ ${ }^{4}$ Faculty of Environment, Thai Nguyen University of Agriculture and Forestry (TUAF), Thai Nguyen \\ city, Vietnam. \\ ${ }^{5}$ Faculty of Engineering and IT, University of Technology, Sydney (UTS), Sydney, Australia \\ ${ }^{6}$ University of Wuppertal, School of Architecture and Civil Engineering, Institute of Foundation \\ Engineering, Water- and Waste-Management, Laboratory of Soil- and Groundwater-Management, \\ Pauluskirchstraße 7, 42285 Wuppertal, Germany \\ ${ }^{7}$ Department of Environment, Energy and Geoinformatics, Sejong University, Seoul 05006, Korea \\ ${ }^{8}$ Sustainable Management of Natural Resources and Environment Research Group, Faculty of \\ Environment and Labour Safety, Ton Duc Thang University, Ho Chi Minh City, Vietnam. \\ Corresponding author: (H.N. Tran)
}

Email: trannguyenhai@ @dt.edu.vn

Tel: +84-0967-070-062

\begin{abstract}
Calcium carbonate $\left(\mathrm{CaCO}_{3}\right)$-enriched biomaterial derived from freshwater mussel shells (FMS) was used as a non-porous biosorbent to explore the characteristics and mechanisms of cadmium adsorption in aqueous solution. The adsorption mechanism was proposed by comparing the FMS properties before and after adsorption alongside various adsorption studies. The FMS biosorbent was characterized using nitrogen adsorption/desorption isotherm, X-ray diffraction, scanning electron microscopy with energy dispersive spectroscopy, Fourier-transform infrared spectroscopy, and point of zero charge. The results of batch experiments indicated that FMS possessed an excellent affinity to $\mathrm{Cd}$ (II) ions within solutions $\mathrm{pH}$ higher than 4.0. An increase in ionic strength resulted in a significant decrease in the amount of Cd(II) adsorbed onto FMS. Kinetic study demonstrated that the adsorption process quickly reached equilibrium at approximately $60 \mathrm{~min}$. The FMS biosorbent exhibited the Langmuir maximum adsorption capacity as follows: $18.2 \mathrm{mg} / \mathrm{g}$ at $10{ }^{\circ} \mathrm{C}<26.0 \mathrm{mg} / \mathrm{g}$ at $30{ }^{\circ} \mathrm{C}<28.6$ $\mathrm{mg} / \mathrm{g}$ at $50{ }^{\circ} \mathrm{C}$. The $\mathrm{Cd}(\mathrm{II})$ adsorption process was irreversible, spontaneous $\left(-\Delta G^{\circ}\right)$, endothermic $\left(+\Delta H^{\circ}\right)$, and more random $\left(+\Delta S^{\circ}\right)$. Selective order $(\mathrm{mmol} / \mathrm{g})$ of metal cations followed as $\mathrm{Pb}^{2+}>\mathrm{Cd}^{2+}$ $>\mathrm{Cu}^{2+}>\mathrm{Cr}^{3+}>\mathrm{Zn}^{2+}$. For column experiments, the highest Thomas adsorption capacity $(7.86 \mathrm{mg} / \mathrm{g})$ was achieved at a flow rate $(9 \mathrm{~mL} / \mathrm{min})$, initial Cd(II) concentration $(10 \mathrm{mg} / \mathrm{L})$, and bed height $(5 \mathrm{~cm})$. The Cd(II) removal by FMS was regarded as non-activated chemisorption that occurred very rapidly (even at a low temperature) with a low magnitude of activation energy. Primary adsorption mechanism was surface precipitation. Cadmium precipitated in the primary $(\mathrm{Cd}, \mathrm{Ca}) \mathrm{CO}_{3}$ form with a calcite-type structure on the FMS surface. A crust of rhombohedral crystals on the substrate was observed by SEM. Freshwater mussel shells have the potential as a renewable adsorbent to remove cadmium from water.
\end{abstract}

Keywords: Freshwater mussel shells; adsorption mechanism; cadmium; surface precipitation; $(\mathrm{Cd}, \mathrm{Ca}) \mathrm{CO}_{3}$. 


\section{Introduction}

Potentially toxic metals present in either discharged water from industrial activities and sent downstream or originating from environmental geochemistry, inevitably cause some potential health risks for humans and pose a great threat to the environment (Pourret and Bollinger, 2018). Cadmium (Cd) exerts manifestly damaging effect on people's lungs, kidneys, and bones (Liu et al., 2018). Human cadmium exposures through the food supply were identified as early as the end of World War II in Fuchu, Japan. A cadmium toxicology-related disease (Japanese for Ouch-Ouch disease) is a bone disease characterized by fractures and severe pain (Nordberg, 2009). Subsequently, the World Health Organization (WHO) and the United States Environmental Protection Agency (EPA) established a maximum acceptable concentration for cadmium in drinking water to be $0.003 \mathrm{mg} / \mathrm{L}$ (Siegel, 2002).

Numerous conventional treatment techniques have been applied to remove cadmium from water environments, such as coagulation/flocculation, flotation, ion exchange, membrane, adsorption, electrochemical treatment, and chemical precipitation (Carolin et al., 2017). Among such existing methods, adsorption has been acknowledged to be the most economically favorable method; it requires low energy consumption for removing cadmium from water environments, even at a very low cadmium concentration. In the literature, geological and biogenic calcium carbonate $\left(\mathrm{CaCO}_{3}\right)$ has attracted much attention from the scientific community and been applied as an abundant and costeffective source for developing $\mathrm{CaCO}_{3}$-rich materials. Such composite biomaterials demonstrated a high affinity to many potentially harmful metals (i.e., $\mathrm{Cd}, \mathrm{Cu}, \mathrm{Pb}, \mathrm{Ni}$, and $\mathrm{Zn}$ ) (Flores-Cano et al., 2013; Ahmad et al., 2012; Du et al., 2011; Hsu 2009; Shaheen et al., 2013) and rare earth elements (Zhou et al., 2018) in water media.

Similar to geological calcium carbonate, biogenic calcium carbonate commonly exists in tw o certain polymorphs with similar crystal structure and thermodynamic stability: calcite (a trigonal shape) and aragonite (an orthorhombic shape) (Feng et al., 2000). Generally, biogenic calcite is the primary constituent of relevant shells of: (1) marine organisms, for example oyster shells (accounting for approximately $61 \% \mathrm{CaCO}_{3}$ by weight) ( $\mathrm{Du}$ et al., 2011; $\left.\mathrm{Hsu}, 2009\right)$ and coral waste $(>35 \%)$ (Ahmad et al., 2012); and (2) eggshells (85-95\%) (Flores-Cano et al., 2013; Ahmad et al., 2012; Shaheen et al., 2013). Meanwhile, biogenic aragonite forms naturally in almost all mollusk shells $\left(>95 \% \mathrm{CaCO}_{3}\right)$ - razor clam shells and mussel shells (96\%) (Du et al., 2011), golden apple snail shell $(\sim 93 \%)$ (Zhao et al., 2016) - which is relatively close to commercial calcium carbonate ( 99\%) (Hamester et al., 2012). Notably, some authors emphasized that aragonite exhibited excellent adsorption capacity to potentially toxic metals than calcite in the same operational circumstances ( $\underline{\mathrm{Du}}$ et al., 2011; Prieto et al., 2003). For this reason, biogenic aragonite can be considered a potential adsorbent for water remediation.

In essential, surface precipitation is classified as a typically chemical adsorption phenomenon (chemisorption). Although the surface precipitation (i.e., metal hydroxide and metal-carbonate formations) has been early identified as the principal adsorption mechanism of potentially toxic metals (i.e., cadmium) onto $\mathrm{CaCO}_{3}$-enriched materials, several indispensable issues should be systematically investigated and further discussed. Herein, we utilized the freshwater mussel shells (FMS) with a high $\mathrm{CaCO}_{3}$ content (approximate 95\%) as a green biosorbent to adsorb toxic cadmium in aqueous solution. The behaviours of cadmium adsorption onto FMS were thoroughly investigated through batch and column experiments under various operational conditions. In addition, the adsorption mechanism was discussed by comparing the changes in some appropriate properties of FMS after cadmium adsorption along with the adsorption studies.

\section{Materials and methods}

\subsection{Preparation of $\mathrm{CaCO}_{3}$-enriched biosorbent}

The wastes of freshwater mussel shells were collected from the seafood restaurant located in Thai Nguyen city, Vietnam. They were washed three times with ordinary tap water and air-dried under 
sunlight. The dried FMS wastes were then soaked with sulfuric acid (50\%) to remove some solubleorganic compounds present in their surface. Subsequently, it was repeatedly washed with distilled water to remove any residual acid until the $\mathrm{pH}$ of filtrate reached $\mathrm{pH}$ constant. After being left to dry for $24 \mathrm{~h}$ in an oven $\left(105^{\circ} \mathrm{C}\right)$, it was ground and sieved to obtain particles $\leq 5 \mathrm{~mm}$ in size. The obtained FMS particles ( $\sim 5 \%$ moisture) were then stored in some brown bottles for further experiments.

\subsection{Property of $\mathrm{CaCO}_{3}$-enriched biosorbent}

The textural property of FMS was determined by nitrogen adsorption/desorption isotherm (Coulter, USA). Its surface morphology and element composition of FMS was observed by a scanning electron microscope coupled with energy dispersive X-ray spectroscopy (Hitachi S-4800). Its crystal structure was obtained by X-ray diffraction pattern using XRD-D8 ADVANCE, with the $\mathrm{Cu} \mathrm{Ka}$ radiation $(\lambda=1,5417 \AA)$. The scan angle covered $15^{\circ}<2 \theta<70^{\circ}$ at a scan speed of $3 \% \mathrm{~min}$. The presence of surface functional groups was detected using Fourier transform infrared spectroscopy (FT/IR-6300). A spectrum was scanned from 4000 to $500 \mathrm{~cm}^{-1}$. The $\mathrm{pH}$ value at the point of zero charge ( $\left.\mathrm{pH}_{\mathrm{PZC}}\right)$ was commonly determined utilizing the drift method (Tran et al., 2016).

\subsection{Study of cadmium adsorption}

A stock cadmium solution (1000 mg/L) was prepared by accurately dissolving $2.744 \mathrm{~g}$ $\mathrm{Cd}\left(\mathrm{NO}_{3}\right)_{2} \bullet 4 \mathrm{H}_{2} \mathrm{O}$ (purchased from Merch) in $1 \mathrm{~L}$ of double distilled water. All working solutions of various cadmium concentrations were obtained by directly diluting from the stock solution with distilled water.

\subsubsection{Batch experiment}

The $\mathrm{pH}$ values of working cadmium solutions were adjusted to target values by adding $1 \mathrm{M}$ $\mathrm{HCl}$ and $1 \mathrm{M} \mathrm{NaOH}$. Approximately $0.2 \mathrm{~g}$ of FMS was then transferred into a $250 \mathrm{~mL}$ Erlenmeyer flask containing $50 \mathrm{~mL}$ of cadmium concentration (a target $\mathrm{pH}$ value). The flask was covered by parafilm and shaken at $150 \mathrm{rpm}$. Following the desired time, the mixture of FMS and cadmium was separated using Whatman No.1 filter paper (pore size of $0.22 \mu \mathrm{m}$ ). The cadmium concentration in the solution was determined by atomic absorption spectrometry (Hitachi Z 2000, Japan). Detailed information on the experimental conditions (i.e., $\mathrm{pH}$ solution, contact time, cadmium concentration, $\mathrm{NaCl}$ concentration, and temperature) was provided with each figure. The amounts of cadmium adsorbed onto biosorbent at equilibrium $\left(q_{\mathrm{e}} ; \mathrm{mg} / \mathrm{g}\right)$ and any time $t\left(q_{\mathrm{t}} ; \mathrm{mg} / \mathrm{g}\right)$ were calculated according to a mass balance equation as shown below:

$$
\begin{aligned}
& q_{e}=\frac{\left(C_{o}-C_{e}\right) V}{m_{1}} \\
& q_{t}=\frac{\left(C_{o}-C_{t}\right) V}{m_{1}}
\end{aligned}
$$

where $C_{\mathrm{o}}(\mathrm{mg} / \mathrm{L}), C_{\mathrm{t}}(\mathrm{mg} / \mathrm{L})$, and $C_{\mathrm{e}}(\mathrm{mg} / \mathrm{L})$ are the cadmium concentrations in solution at beginning, time any time $t$, and equilibrium, respectively; $V(\mathrm{~L})$ is the working volume of cadmium solution; and $m_{l}(\mathrm{~g})$ is the dry weight of used biosorbent.

The metal selectivity study was conducted using an identical molar concentration of metals. Approximately $0.2 \mathrm{~g}$ of FMS was added to the flask containing $50 \mathrm{~mL}$ of various metal ions. These metals $\left(\mathrm{Cd}^{2+}, \mathrm{Cr}^{3+}, \mathrm{Pb}^{2+}, \mathrm{Zn}^{2+}\right.$, and $\left.\mathrm{Cu}^{2+}\right)$ were prepared from the standard solutions $(1000 \mathrm{mg} / \mathrm{L}$; purchased from Merch), such as $\mathrm{Cd}\left(\mathrm{NO}_{3}\right)_{2}, \mathrm{Cr}\left(\mathrm{NO}_{3}\right)_{3}, \mathrm{~Pb}\left(\mathrm{NO}_{3}\right)_{2}, \mathrm{Zn}\left(\mathrm{NO}_{3}\right)_{2}$, and $\mathrm{Cu}\left(\mathrm{NO}_{3}\right)_{2}$, respectively. The molar concentration of each metal was set at $2.0 \mathrm{mmol} / \mathrm{L}$. The experimental conditions for competitive adsorption were fixed at $30^{\circ} \mathrm{C}, \mathrm{pH} 6.0,3 \mathrm{~h}$, and $0 \mathrm{M} \mathrm{NaCl}$. 
The adsorption reversibility was determined by a desorption experiment. A given mass of Cd ions-laden biosorbent (approximately $0.2 \mathrm{~g}$ ) was desorbed using $50 \mathrm{~mL}$ of every desorbing agent. The desorbing agents used in this study comprised distilled water $(\mathrm{pH} 2.0), \mathrm{HCl}, \mathrm{NaCl}$, and $\mathrm{CaCl}_{2}$. The percentage of cadmium desorbed from the laden biosorbent was calculated by a mass balance equation.

\subsubsection{Continuous column experiment}

Dynamic adsorption was examined in an upflow fixed-bed column system. The inside diameter of the PVC column was $4.2 \mathrm{~cm}$, and the length was $50 \mathrm{~cm}$. The column was loaded with FMS between a sand layer $(1 \mathrm{~cm})$ covered on the stainless-steel sieve's surface at the column bottom to avoid an unexpected loss of biosorbent fragments during the adsorption study. The effluent residual samples were collected at specified intervals to determine the cadmium concentrations. Information on the experimental conditions (i.e., flow rate, initial cadmium concertation, and bed height) is listed along with each figure.

Generally, breakthrough time $\left(t_{\mathrm{b}} ; \mathrm{min}\right)$ and the FMS adsorption capacity $\left(q_{\mathrm{b}} ; \mathrm{mg} / \mathrm{g}\right)$ at breakthrough time can be calculated when effluent cadmium concentration reaches $10 \%$ of influent concentration $\left(C_{\mathrm{t}} / C_{\mathrm{o}}=0.1\right)$. Meanwhile, exhaustion (or saturation) time $\left(t_{\mathrm{s}} ; \mathrm{min}\right)$ and adsorption capacity $\left(q_{\mathrm{s}} ; \mathrm{mg} / \mathrm{g}\right)$ at exhaustion time can be obtained when $C_{\mathrm{t}} / C_{\mathrm{o}}=0.95$.

$$
\begin{aligned}
& q_{b}=\frac{Q}{1000}\left(C_{o}-\frac{C_{b}}{2}\right) \frac{t_{b}}{m_{2}} \\
& q_{s}=\frac{Q}{1000}\left(C_{o}-\frac{C_{s}}{2}\right) \frac{t_{s}}{m_{2}}
\end{aligned}
$$

where $C_{\mathrm{o}}(\mathrm{mg} / \mathrm{L})$ and $C_{\mathrm{t}}(\mathrm{mg} / \mathrm{L})$ are the cadmium concentrations in solution at beginning and equilibrium, respectively; $Q(\mathrm{~mL} / \mathrm{min})$ is the volumetric flow rate; and $m_{2}$ is the mass of FMS used in the column. All experiments were conducted in duplicate, and the mean of the quantitative results was calculated. If the bias was greater than $15 \%$ then the data were not used.

\subsubsection{Statistical analysis}

Each adsorption experiment was conducted in triplicate, and the data were reported as average \pm standard deviation (SD). The model parameters of adsorption kinetic and isotherm were calculated by the non-linear technique. Chi-square statistic $\left(\chi^{2}\right)$ was used to estimate the differences between the experimental data $\left(q_{\mathrm{e} \text {,exp }}\right)$ and data calculated using the models $\left(q_{\mathrm{e} \text {,model }}\right)$. If the $q_{\mathrm{e} \text {,exp }}$ values are similar to the $q_{\mathrm{e} \text {,model }}$ values, $\chi^{2}$ is close to zero. In contrast, a high $\chi^{2}$ value demonstrates high bias between the $q_{\mathrm{e}, \text { exp }}$ and $q_{\mathrm{e} \text {,model values. }}$

\section{Results and discussion \\ 3.1. Biosorbent property}

The analysis result of nitrogen adsorption/desorption isotherm (data not showed) demonstrated that the FMS biosorbent is categorized as a non-porous material because of its poor textural properties, such as a low Brunauer-Emmett-Teller specific surface area $\left(S_{\mathrm{BET}} ; 1.45 \mathrm{~m}^{2} / \mathrm{g}\right)$ and total pore volume $\left(0.0002 \mathrm{~cm}^{3} / \mathrm{g}\right)$. This outcome well agrees with the morphological observation of FMS in Figure 1a. Likewise, many researchers found that the $\mathrm{CaCO}_{3}$-rich biosorbent possessed a low $S_{\mathrm{BET}}$ value, for instance $2.09 \mathrm{~m}^{2} / \mathrm{g}$ for golden apple snail shells (Zhao et al., 2016), $1.81 \mathrm{~m}^{2} / \mathrm{g}$ for oyster shells (Alidoust et al., 2015), $0.21 \mathrm{~m}^{2} / \mathrm{g}$ for dead calcareous skeletons (Lim and Aris, 2014), and $0.07 \mathrm{~m}^{2} / \mathrm{g}$ for chicken eggshells (Flores-Cano et al., 2013). In this case, the surface area was not a determining factor of the adsorption capacity FMS toward various contaminants in water media, including cadmium. 


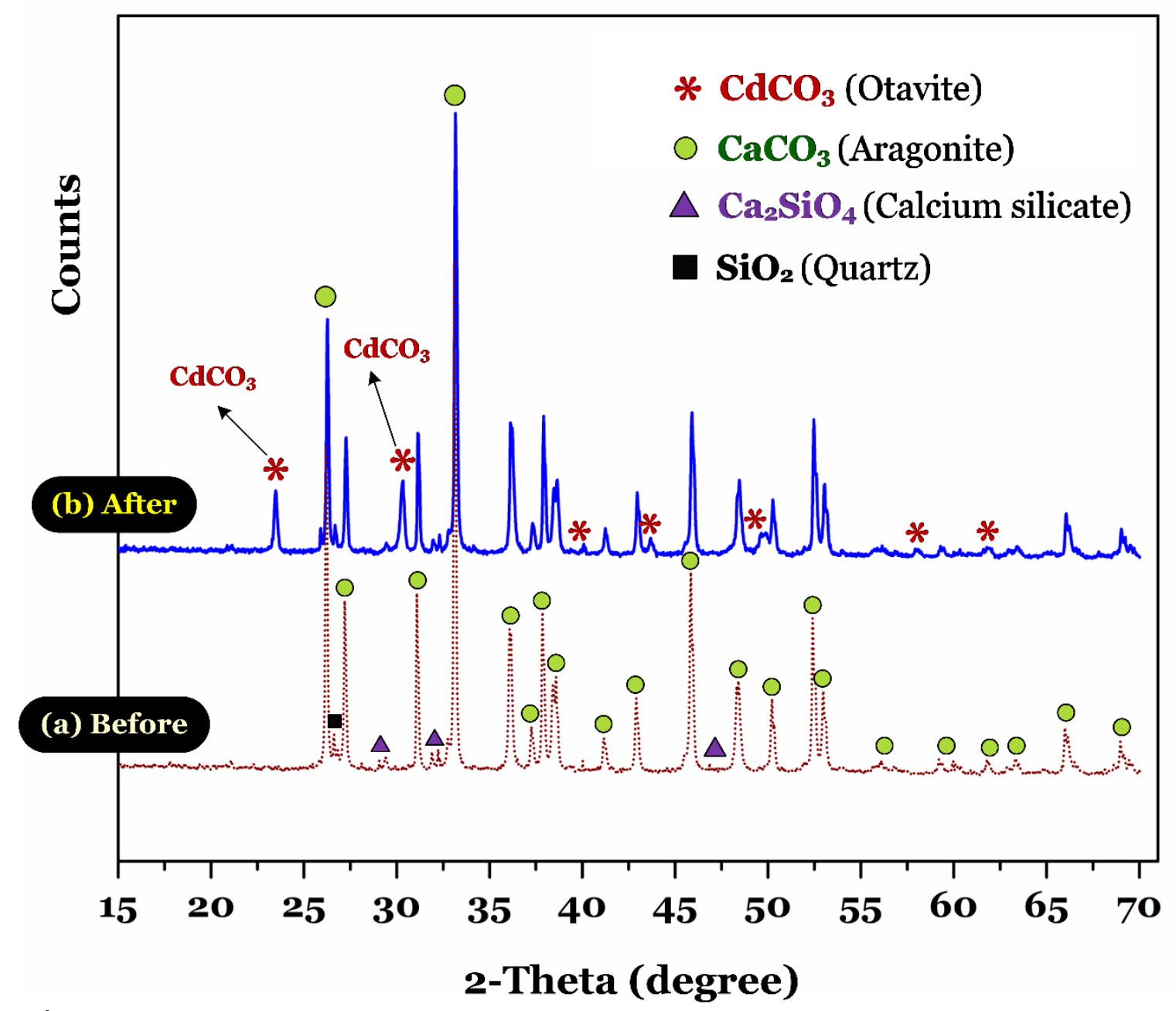

Figure 1. Representative XRD spectra of (a) pristine FMS and (b) cadmium-loaded FMS

As stated previously in the introduction Section, freshwater mussel shells are classified as a biogenic aragonite- the most soluble form of crystalline $\mathrm{CaCO}_{3}$. The XRD spectrum of pristine FMS (Figure 2a) indicated that almost all characteristic peaks were well indexed to a calcium carbonate polymorph with a highly aragonite crystal structure (the standard JCPDS file, No. 5-0453). In addition, the XRD data confirmed the presence of small amounts of minerals $\left(6.2 \% \mathrm{Ca}_{2} \mathrm{SiO}_{4}\right)$ and quartz $(3.0 \%$ $\left.\mathrm{SiO}_{2}\right)$, suggesting that FMS is a pure biogenic aragonite $\left(98.8 \% \mathrm{CaCO}_{3}\right)$. According to Xiong et al. (2011), the freshwater mussel shells contain the major constituent of $\mathrm{CaO}(52.6 \%$; wt.) in the total chemical composition (determined by Wavelength dispersive $\mathrm{X}$-ray fluorescence spectrometer); the other auxiliary contributions belong to $\mathrm{SiO}_{2}(2.1 \%), \mathrm{Al}_{2} \mathrm{O}_{3}(1.4 \%), \mathrm{MgO}(0.2 \%), \mathrm{Fe}_{2} \mathrm{O}_{3}(0.15 \%), \mathrm{K}_{2} \mathrm{O}$ $(0.05 \%)$, and $\mathrm{Na}_{2} \mathrm{O}(<0.01 \%)$. Similarly, the EDS analysis (Figure 3a) revealed that FMS is mainly composed of carbon $(30.05 \% \pm 2.69)$, oxygen $(55.63 \% \pm 4.73)$, and calcium $(9.33 \% \pm 0.35)$. Cadmium in solution can react with $\mathrm{CaCO}_{3}$ and replace calcium in the crystals of aragonite because of their similar ionic radii (Zhao et al., 2016). This phenomenon has been known as an isomorphic substitution. 


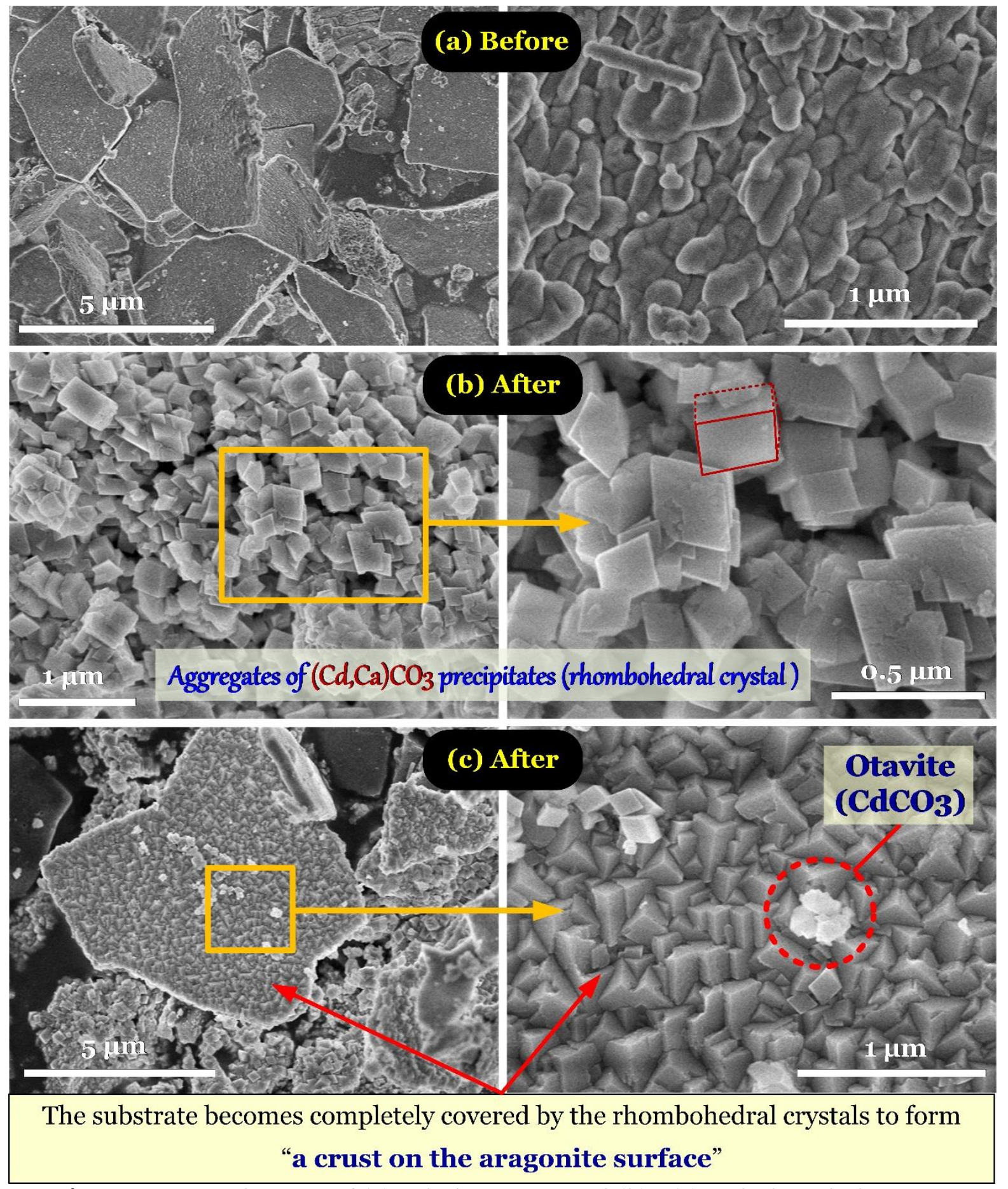

Figure 2. SEM images of (a) pristine FMS, and (b)-(c) cadmium-laden FMS 

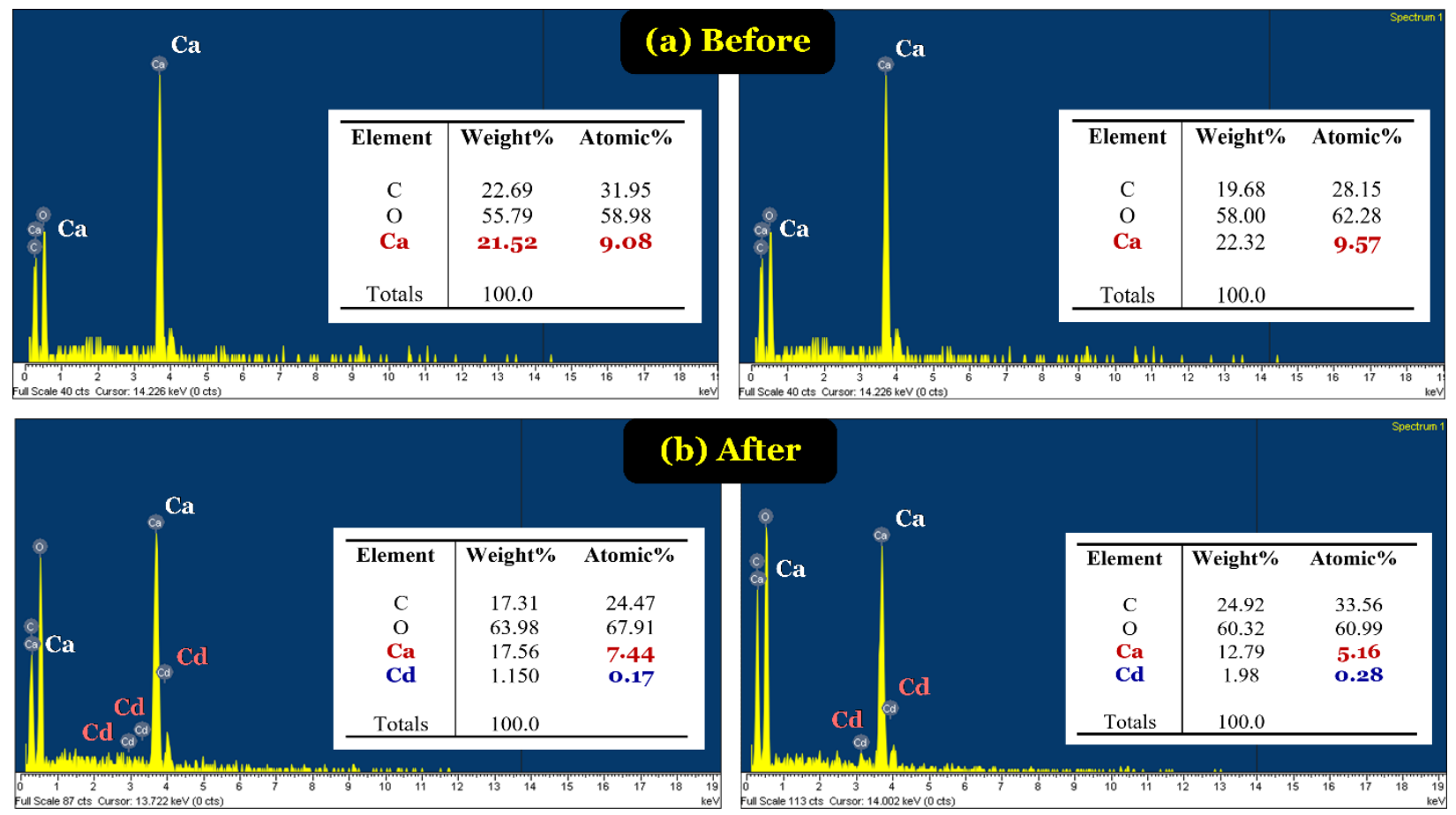

Figure 3. EDS spectra of (a) pristine FMS, and (b) cadmium-laden FMS

Furthermore, quantitative information on the dominant functional groups on the FMS surface is provided in Figure 4. A broad peak at approximately $3445 \mathrm{~cm}^{-1}$ is assigned to the hydroxy group in physically adsorbed water (moisture content). Two small peaks at around $2920 \mathrm{~cm}^{-1}$ and $2520 \mathrm{~cm}^{-1}$ are attributed to the stretching of $\mathrm{C}-\mathrm{H}$ bonds of proteins (possibly originated from the FMS metabolism) and the $-\mathrm{OH}$ group of $\mathrm{HCO}_{3}^{-}$(Zhao et al., 2016). The presence of $\mathrm{CaCO}_{3}$ polymorph can be recognized at several pronounced peaks at: (1) $1630 \mathrm{~cm}^{-1}, 1465 \mathrm{~cm}^{-1}, 863 \mathrm{~cm}^{-1}$ (out-of-plane bending model), and $705 \mathrm{~cm}^{-1}$ (in-plane bending model) corresponding to the carbonate group internal $\mathrm{C}-\mathrm{O}$ vibrations and (2) $1785 \mathrm{~cm}^{-1}$ and $1080 \mathrm{~cm}^{-1}$ attributable to the $\mathrm{C}=\mathrm{O}$ groups of carbonate ions (Lim and Aris, 2014; Nan et al., 2008). Furthermore, Lim and Aris (2014) pointed out that the carbonyl (C=O) group present in eggshells and coral wastes is expected to function as an active group for complexation with toxic metal ions (i.e., $\mathrm{Pb}^{2+}, \mathrm{Cd}^{2+}$, and $\mathrm{Cu}^{2+}$ ). Clearly, $\mathrm{XRD}$ and FTIR confirmed the existence of $\mathrm{CaCO}_{3}$ as the major constituent in the FMS powders. 


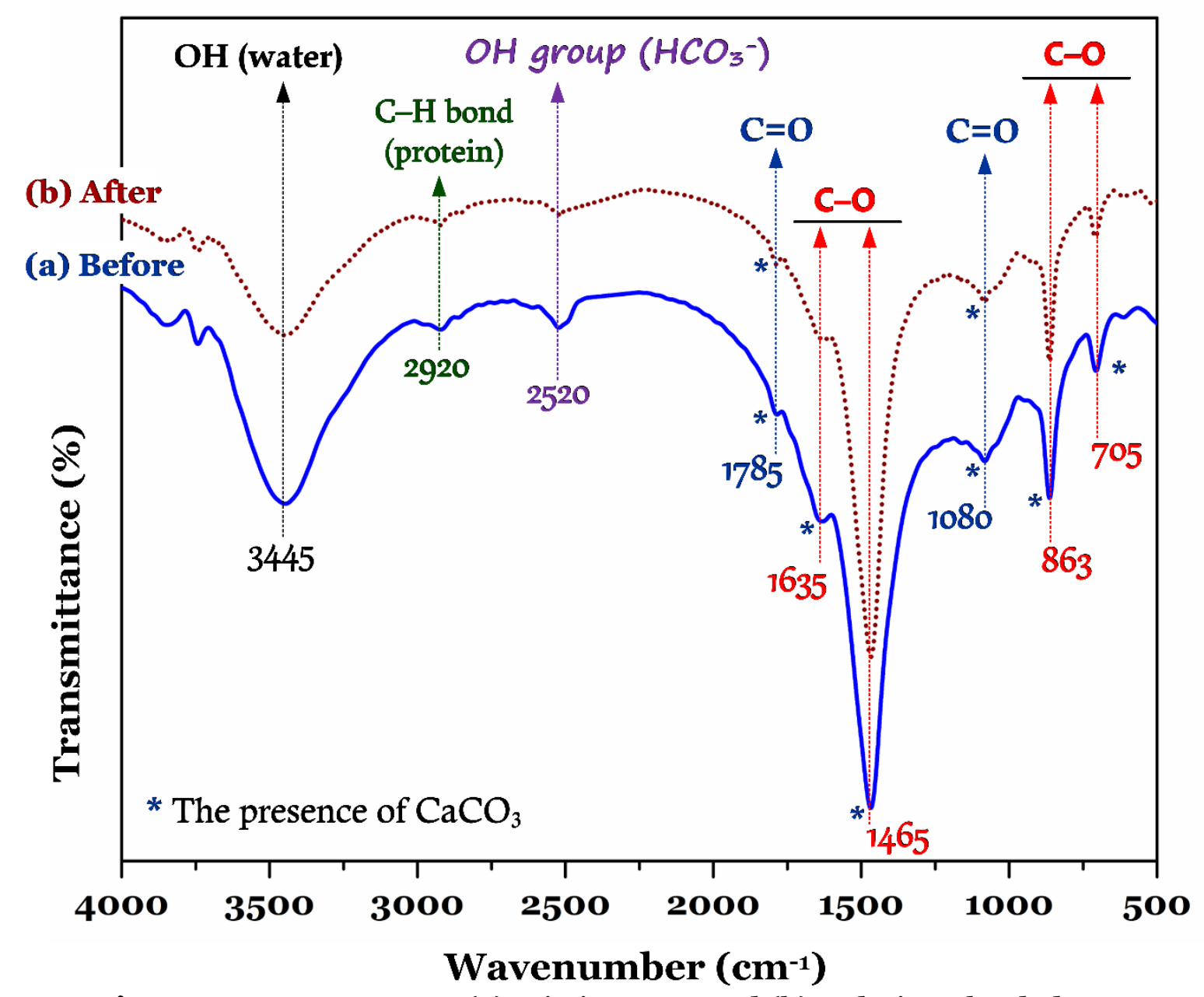

Figure 4. FTIR spectra of (a) pristine FMS and (b) cadmium-loaded FMS

\subsection{Adsorption performance in batch experiments}

\subsubsection{Effect of $\mathrm{pH}$ and ionic strength}

Figure 5a indicates that the adsorption process is strongly dependent on solution $\mathrm{pH}\left(\mathrm{pH}_{\text {solution }}\right)$ values. The amount of $\mathrm{Cd}$ (II) adsorption onto FMS increased when $\mathrm{pH}_{\text {solution }}$ increased, with its adsorption capacity reaching plateau values at $\mathrm{pH}_{\text {solutions }}$ higher than 4.0. This conclusion is well consistent with observations documented in (Veneu et al., 2017; Sdiri et al., 2012). As presented in Figure $5 \mathrm{~b}$, the $\mathrm{pH}$ PZC of FMS is 10.8 , which is identical to the finding of other $\mathrm{CaCO}_{3}$-enriched materials, such as 11.4 for eggshells (Flores-Cano et al., 2013), 10.6 for calcined eggshells (Slimani et al., 2014), and 9.2 for mussel shells (El Haddad, 2016). According to $\mathrm{pH}_{\mathrm{PZC}}$, the dominant surface of FMS will be positively charged when $\mathrm{pH}_{\text {solution }}$ exceeds $\mathrm{pH}_{\mathrm{PZC}}$, and vice versa. This means that FMS exhibited a dominantly positively charged surface for all working solutions $\mathrm{pH}$ in this study. 

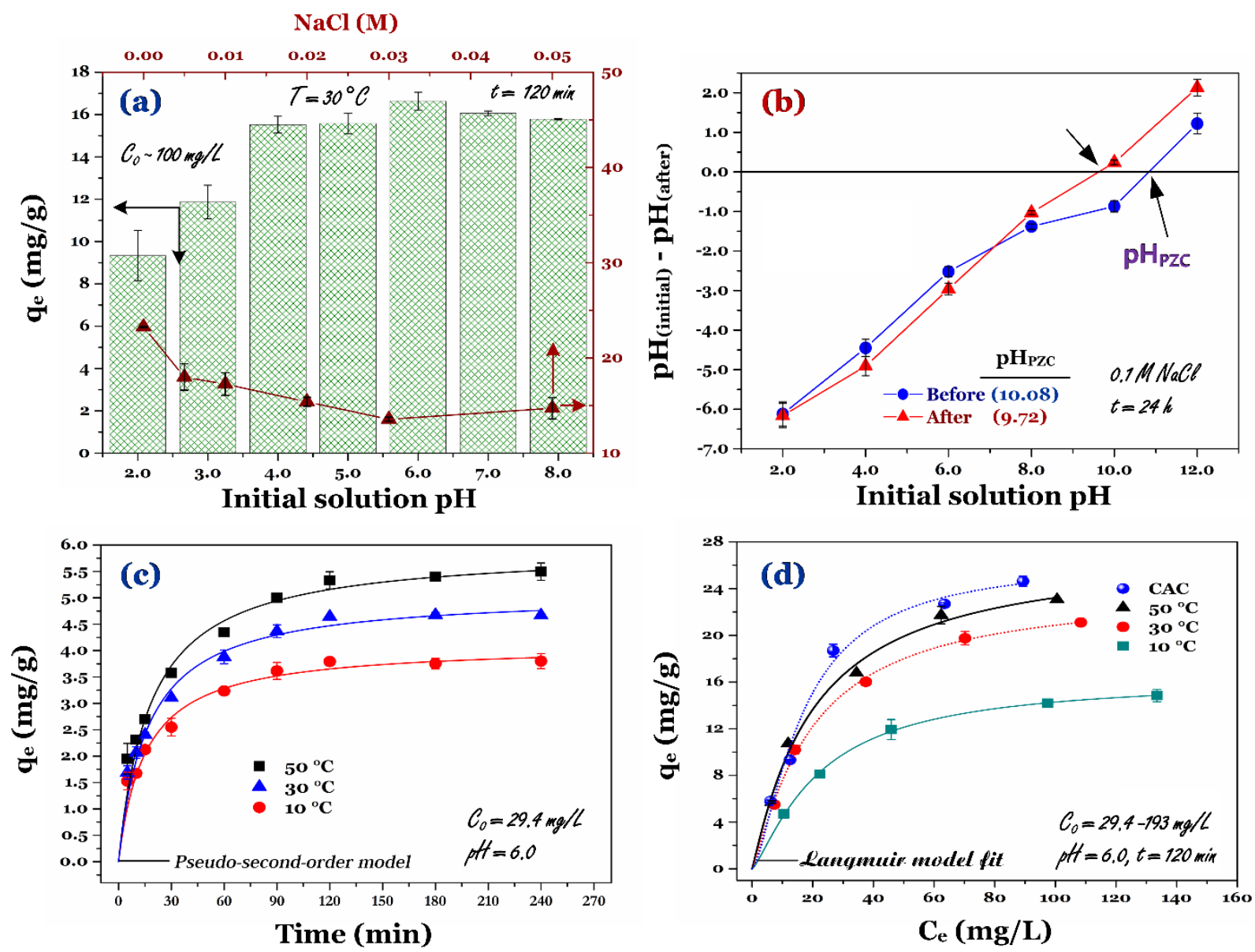

Figure 5. Batch experiments: (a) effect of solution $\mathrm{pH}$ and ionic strength, (b) $\mathrm{pH}$ PZC of FMS, (c) adsorption kinetics, and (d) adsorption isotherm

As discussed in the literature, when $\mathrm{CaCO}_{3}$-enriched biogenic materials contact with aqueous solution, the calcareous layer in the biogenic material can spontaneously dissolve to release calcium $\left(\mathrm{Ca}^{2+}\right)$ and bicarbonate $\left(\mathrm{HCO}_{3}{ }^{-}\right)$constituents into solution (Equations 5-6) (Alidoust et al., 2015; Ismail and Aris, 2013; Kuh and Kim, 2000). For example, Ismail and Aris (2013) analysed the mineralogy state of aqueous solution, finding that the increment of calcium and bicarbonate concentrations in the solution resulted from the dissolution of biogenic $\mathrm{CaCO}_{3}$ clamshells. They also concluded that the concentration of $\mathrm{Ca}^{2+}$ and $\mathrm{HCO}_{3}{ }^{-}$ions in the solution increased after cadmium adsorption, suggesting that the substitution process of $\mathrm{Cd}^{2+}$ with $\mathrm{Ca}^{2+}$ (also defined as ion exchange) was mainly responsible for cadmium uptake in the solution.

\begin{tabular}{|l|c|}
\hline$\equiv \mathrm{CaCO}_{3}(\mathrm{~s}) \rightarrow \mathrm{Ca}^{2+}+\mathrm{CO}_{3}^{2-}$ & (5) \\
\hline $\mathrm{CO}_{3}^{2-}+\mathrm{H}_{2} \mathrm{O} \rightarrow \mathrm{HCO}_{3}^{-}+\mathrm{OH}^{-}$ & (6) \\
\hline $\mathrm{HCO}_{3}^{-}+\mathrm{H}^{+} \rightleftharpoons \mathrm{H}_{2} \mathrm{O}+\mathrm{CO}_{2}(\mathrm{~g})$ & $(8)$ \\
\hline$\equiv \mathrm{CaCO}_{3}(\mathrm{~s})+\mathrm{Cd}^{2+} \rightarrow \equiv \mathrm{CdCO}_{3}+\mathrm{Ca}^{2+}$ & (9) \\
\hline$\equiv \mathrm{CaCO}_{3}(\mathrm{~s})+\mathrm{Cd}^{2+}+\mathrm{CO}_{3}^{2-} \rightarrow \equiv(\mathrm{Ca}, \mathrm{Cd}) \mathrm{CO}_{3} \downarrow$ \\
\hline $\mathrm{CO}_{3}^{2-}+\mathrm{Cd}^{2+} \rightarrow \equiv \mathrm{CdCO}_{3} \downarrow$ & (10) \\
\hline
\end{tabular}


As illustrated in Figure 5a, the adsorption process still functioned adequately when $\mathrm{pH}_{\text {solution }}$ was lower than the $\mathrm{pH}_{\mathrm{PZC}}$ of FMS. Especially, the FMS biosorbent can adsorb $\mathrm{Cd}^{2+}$ ion at a low $\mathrm{pH}_{\text {soltion }}$ although the excess $\mathrm{H}^{+}$and $\mathrm{H}_{3} \mathrm{O}^{+}$ions present in $\mathrm{pH} 2.0$ demonstrated a strong competition with $\mathrm{Cd}^{2+}$ ions for the limited adsorption sites on the biosorbent's surface. The results suggested that:

(1) certain chemical interactions with sufficient energy could overcome the surface-electrostatic repulsive force, such as ion exchange (Equation 8) or/and surface precipitation (Equations 9-10); and (2) the electrostatic attraction played an insignificant role in adsorption mechanism. The same result has been reported in other studies (Veneu et al., 2017; Sdiri et al., 2012). Notably, in strong acidic media $(\mathrm{pH}=2.0)$, the reaction between abundant hydrogen $\left(\mathrm{H}^{+}\right)$ions and $\mathrm{HCO}_{3}{ }^{-}$ions spontaneously occurs; as a result, carbon dioxide was formed and escaped from the solution (Equation 7). In other

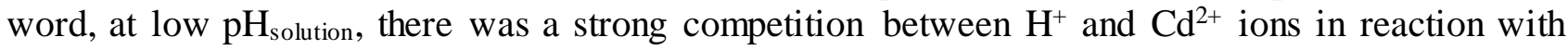
carbonate species in the solution (hao et al., 2016). Furthermore, the enhanced adsorption capacity of FMS within increasing solution $\mathrm{pH}$ was because a decrease in the amount of hydrogen ions in the solution and an increase in the amounts of $\mathrm{HCO}_{3}{ }^{-}$and $\mathrm{CO}_{3}{ }^{2-}$ anions in the solution.

Moreover, the effect of adding $\mathrm{NaCl}$ salt at different concentration is depicted in Figure 5a. Clearly, the adsorption capacity of FMS strongly depended on the presence of $\mathrm{Na}^{+}$ions in solution. The $q_{\mathrm{e}}$ values significantly decreased when $\mathrm{NaCl}$ concentration increased from $0.005 \mathrm{M}$ to $0.05 \mathrm{M}$. This is presumably because strong competition occurred between $\mathrm{Na}^{+}$ions and $\mathrm{Cd}^{2+}$ ions for limited active exchangeable sites on the surface of FMS. Notably, as aforementioned in the literature, when a $\mathrm{CaCO}_{3}$-enriched material (i.e., aragonite) contacts with solution, the calcareous layer in FMS can dissolve to release $\mathrm{Ca}^{2+}$ and $\mathrm{CO}_{3}{ }^{2-}$ ions into solution (Zhou et al., 2017; Köhler et al., 2007). The released $\mathrm{Ca}^{2+}$ ions played a principal role in reacting with $\mathrm{Cd}^{2+}$ ions and $\mathrm{CO}_{3}^{2-}$ ions to form the solidsolution nuclei. Therefore, a decrease in the biosorbent's adsorption capacity within existing $\mathrm{NaCl}$ was presumably because the presence of $\mathrm{Na}^{+}$or $\mathrm{Cl}^{-}$ions in the solution inhibited the formation of insoluble $\mathrm{CdCO}_{3}$ or $(\mathrm{Ca}, \mathrm{Cd}) \mathrm{CO}_{3}$.

\subsubsection{Adsorption kinetics}

The time-dependent nature of the cadmium adsorption process at different operation temperatures is displayed in Figure 5c. The FMS adsorbent is a non-porous material with its limited pore volume; therefore, the intraparticle diffusion played a negligible role in the removal process. Clearly, the adsorption process occurred rapidly, and approximately $40 \%$ of cadmium in the solution was removed (adsorbed onto FMS) within $5 \mathrm{~min}$ of contact. The instantaneous adsorption process suggested that FMS has a strong affinity to $\mathrm{Cd}$ (II) ions in solution. Additionally, the amount of $\mathrm{Cd}^{2+}$ ions adsorbed onto FMS reached a true equilibrium within approximately a 60-min duration.

Notably, some other authors have previously identified that the primary adsorption mechanism of potentially toxic metals regarding the surface precipitation of metal-carbonate formation occurred very quickly. For example, McBride $(\underline{1980})$ concluded that the initial chemisorption of $\mathrm{Cd}^{2+}$ ions on calcium carbonate was very rapid. Saleh et al. (2016) confirmed that approximately $74-81 \%$ of copper was removed by sunflower seed husk-derived biochar within the first $5 \mathrm{~min}$, which well agrees with Tran et al. (2016) for cadmium removal by orange peel-prepared biochar $(81-97 \%$ of cadmium removed within the first minute of contact). Similarly, Zhao et al. (2016) reported that more than $85 \%$ cadmium in the solution was adsorbed onto golden apple snail shells within 5 min. Recently, Veneu et al. (2017) found that $\mathrm{CaCO}_{3}$-based adsorbent (algae Lithothamnium calcareum) had a strong binding ability to cadmium in solution, with approximately $58 \%$ of cadmium being removed within 5 min in the kinetic study.

In this study, we applied some helpful kinetic models to describe the cadmium adsorption process onto FMS, such as the pseudo-first-order (PFO; Equation 11), pseudo-second-order (PSO Equation 12), and Elovich (Equation 13) models. The derivation, meanings, and correct application of such selective models have been discussed in detail by Tran et al. (2017). Moreover, activation 
energy $(\mathrm{Ea} ; \mathrm{kJ} / \mathrm{mol})$ is defined as the minimum energy that must be overcome by the adsorbate molecules, and it can be estimated through the Arrhenius equation (Equation 14).

$$
\begin{aligned}
& q_{t}=q_{e}\left(1-e^{-k_{1} t}\right) \\
& q_{t}=\frac{q_{e}^{2} k_{2} t}{1+q_{e} k_{2} t} \\
& q_{t}=\frac{1}{\beta} \ln (1+\alpha \beta t) \\
& \ln k=-\left(\frac{E_{a}}{R}\right) \frac{1}{T}+\ln A
\end{aligned}
$$

where $q_{\mathrm{t}}$ and $C_{\mathrm{t}}$ are the amount of cadmium adsorbed onto biosorbent $(\mathrm{mg} / \mathrm{g})$ and the cadmium concentration $(\mathrm{mg} / \mathrm{L})$ at any $t$, respectively; $k_{2}(\mathrm{~g} / \mathrm{mg} \times \mathrm{min})$ is the pseudo-second-order rate constant; $k_{l}(1 / \mathrm{min})$ is the rate constant of the pseudo-first-order equation; $\alpha(\mathrm{mg} / \mathrm{g} \times \mathrm{min})$ is the initial rate constant; $\beta(\mathrm{mg} / \mathrm{g})$ is the desorption constant during any one experiment; $k$ is the rate constant of applied kinetic models (i.e., the PSO, PFO, or Elovich model); $A$ is the pre-exponential factor (frequently factor); and $R$ and $T$ are the gas constant $(8.314 \mathrm{~J} / \mathrm{mol})$ and temperature, respectively.

As shown in Table 1, the PSO model provided an excellent correlation with the experimental data of time-dependent cadmium adsorption compared to the PFO and Elovich models. Furthermore, the amount of adsorbate adsorbed onto FMS appreciably diminished as temperature increased (Figure $5 \mathrm{c}$ and Table 1), suggesting that the adsorption process was endothermic in nature ( $\underline{\mathrm{Hsu}, 2009}$; Kuh and Kim, 2000). However, the adsorption rate $\left(k_{2}\right)$ decreased as a function of temperature, with the following order: $0.016(\mathrm{~g} / \mathrm{mg} \times \mathrm{min})$ at $10{ }^{\circ} \mathrm{C}>0.012(\mathrm{~g} / \mathrm{mg} \times \mathrm{min})$ at $30{ }^{\circ} \mathrm{C}>0.009(\mathrm{~g} / \mathrm{mg} \times \mathrm{min})$ at $50{ }^{\circ} \mathrm{C}$. This is congruent with the finding of $\mathrm{Hsu}(\underline{2009})$ for the adsorption of $\mathrm{Cu}^{2+}$ or $\mathrm{Ni}^{2+}$ ions in aqueous solution by the oyster shells derived-biosorbent.

Table 1. Relative cadmium adsorption parameters of selective kinetic modes at different temperature

\begin{tabular}{ccccc}
\hline & Unit & \multicolumn{3}{c}{ Temperature } \\
\cline { 3 - 5 } PSO model & & $\mathbf{1 0}{ }^{\circ} \mathbf{C}$ & $\mathbf{3 0}{ }^{\circ} \mathbf{C}$ & $\mathbf{5 0}^{\circ} \mathbf{C}$ \\
$\mathrm{q}_{\mathrm{e}}$ & $\mathrm{mg} / \mathrm{g}$ & 4.114 & 5.091 & 5.931 \\
$\mathrm{k}_{2}$ & $\mathrm{~g} / \mathrm{mg} \times \mathrm{min}$ & 0.016 & 0.012 & 0.009 \\
$\mathrm{R}^{2}$ & - & 0.993 & 0.994 & 0.994 \\
$\chi^{2}$ & - & 0.011 & 0.015 & 0.019 \\
PFO model & & & & \\
$\mathrm{q}_{\mathrm{e}}$ & $\mathrm{mg} / \mathrm{g}$ & 3.683 & 4.528 & 5.240 \\
$\mathrm{k}_{1}$ & $1 / \mathrm{min}$ & 0.050 & 0.046 & 0.044 \\
$\mathrm{R}^{2}$ & - & 0.976 & 0.974 & 0.971 \\
$\chi^{2}$ & - & 0.041 & 0.065 & 0.099 \\
Elovich model $^{\alpha}$ & & & & 0.861 \\
$\beta$ & $\mathrm{mg} / \mathrm{g} \times \mathrm{min}$ & 0.858 & 0.873 & 0.899 \\
$\mathrm{R}^{2}$ & $\mathrm{mg} / \mathrm{g}$ & 1.387 & 1.082 & 0.988 \\
$\chi^{2}$ & - & 0.979 & 0.983 & 0.041 \\
Ea (PSO) & - & 0.035 & 0.043 & \\
Ea (PFO) & $\mathrm{kJ} / \mathrm{mol}$ & & & \\
Ea (Elovich) & $\mathrm{kJ} / \mathrm{mol}$ & & -10.2 & \\
\hline
\end{tabular}


Note: Activation energy was calculated from the Arrhenius equation using the rate constant of the pseudo-second-order (PSO) model ( $\left.\mathrm{y}=1223 \mathrm{x}-8.46 ; R^{2}=0.998\right)$, the pseudo-first-order (PFO) model $\left(\mathrm{y}=291.3 \mathrm{x}-4.036 ; R^{2}=0.9983\right)$, and the Elovich model $\left(\mathrm{y}=-8.804 \mathrm{x}-0.117 ; R^{2}=0.0451\right)$.

\subsubsection{Adsorption isotherms}

Figure 5d provides a typical adsorption isotherm plot of $q_{\mathrm{e}}$ against $C_{\mathrm{e}}$. As expected, the isotherm is classified as a L-type (concave downward) without a strict plateau, implying that cadmi um has a strong affinity for the FMS surface. In this study, we applied several commonly helpful adsorption isotherm models to describe the cadmium adsorption characteristics onto mussel shellsbiosorbent. Specifically, these were the Langmuir (Equation 15), Freundlich (Equation 16), RedlichPeterson (Equation 17), and Dubinin-Radushkevich (Equations 18-20) models. Detailed information on these models can be found in Tran et al. (2017).

$$
\begin{aligned}
& q_{e}=\frac{Q_{\max }^{0} K_{L} C_{e}}{1+K_{L} C_{e}} \\
& q_{e}=K_{F} C_{e}^{n} \\
& q_{e}=\frac{K_{R P} C_{e}}{1+a_{R P} C_{e}^{g}} \\
& q_{e}=q_{D R} e^{-K_{D R} \varepsilon^{2}} \\
& \varepsilon=R T \ln \left(1+\frac{1}{C_{e}}\right) \\
& E=\frac{1}{\sqrt{2 K_{D R}}}
\end{aligned}
$$

where $q_{e}$ and $C_{e}$ are obtained from Eq. $1 ; Q^{o}{ }_{\max }(\mathrm{mg} / \mathrm{g})$ is the Langmuir maximum saturated adsorption capacity of biosorbent; $K_{L}(\mathrm{~L} / \mathrm{mg})$ is the Langmuir constant related to the affinity between an adsorbent and adsorbate; $K_{F}\left[(\mathrm{mg} / \mathrm{g}) /(\mathrm{L} / \mathrm{mg})^{\mathrm{n}}\right]$ is the Freundlich constant, which characterizes the strength of adsorption; $n$ (dimensionless) is a Freundlich intensity parameter; $K_{R P}(\mathrm{~L} / \mathrm{g})$ and $a_{R P}(\mathrm{mg} / \mathrm{L})^{-g}$ are the Redlich-Peterson constants; $g$ (dimensionless) is an exponent whose value must lie between 0 and 1 ; $q_{R D}(\mathrm{mg} / \mathrm{g})$ is the adsorption capacity; $\left.K_{R D}\left(\mathrm{~mol}^{2} / \mathrm{kJ}\right)^{2}\right)$ is the constant related to the adsorption energy; $\varepsilon$ is the Polanyi potential; and $E(\mathrm{~kJ} / \mathrm{mol})$ is the mean adsorption energy.

The corresponding parameters of those models are summarized in Table 2. According to coefficient determination and chi-square statistic, the experimental data of adsorption equilibrium were better described by the Redlich-Peterson (0.988-0.999 and 0.016-1.213) and Langmuir (0.9830.997 and $0.120-1.712)$ models than the Freundlich (0.948-0.968 and 1.150-5.177) and DubininRadushkevich models (0.896-0.913 and 1.094-18.43), respectively.

Table 2. Corresponding cadmium parameters of selective adsorption isotherm models

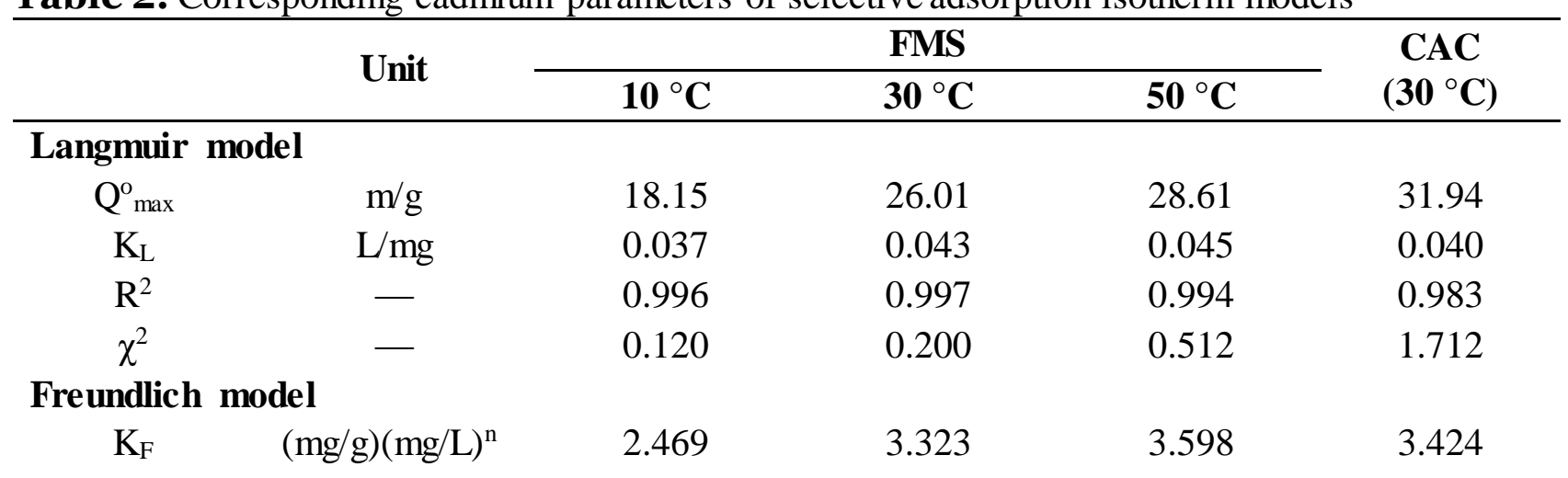




$\begin{array}{llllll}\mathrm{n}_{\mathrm{F}} & - & 0.377 & 0.407 & 0.417 & 0.451 \\ \mathrm{R}^{2} & - & 0.966 & 0.968 & 0.967 & 0.948 \\ \chi^{2} & - & 1.150 & 2.221 & 2.728 & 5.177\end{array}$

Redlich-Peterson model

$\begin{array}{cccccc}\mathrm{K}_{\mathrm{RP}} & \mathrm{L} / \mathrm{g} & 0.527 & 0.990 & 1.204 & 0.960 \\ \mathrm{a}_{\mathrm{RP}} & (\mathrm{mg} / \mathrm{L})^{-\mathrm{g}} & 0.011 & 0.024 & 0.034 & 0.004 \\ \mathrm{~g} & - & 1.009 & 1.003 & 0.992 & 1.021 \\ \mathrm{R}^{2} & - & 0.999 & 0.997 & 0.992 & 0.988 \\ \chi^{2} & - & 0.016 & 0.188 & 0.658 & 1.213\end{array}$

Dubinin-Radushkevich model

$\begin{array}{cccccc}\mathrm{Q}_{\mathrm{DR}} & \mathrm{mg} / \mathrm{g} & 13.82 & 19.41 & 21.10 & 23.52 \\ \mathrm{~K}_{\mathrm{DR}} & \mathrm{mol}^{2} / \mathrm{kJ}^{2} & 31.22 & 16.38 & 11.79 & 20.51 \\ \mathrm{E} & \mathrm{kJ} / \mathrm{mol} & 0.127 & 0.175 & 0.206 & 0.156 \\ \mathrm{R}^{2} & - & 0.896 & 0.913 & 0.907 & 0.901 \\ \chi^{2} & - & 1.094 & 0.783 & 1.927 & 18.43\end{array}$

Note: freshwater mussel shells (FMS) biosorbent and commercial activated carbon (CAC).

Clearly, the adsorption capacity of FMS toward toxic $\mathrm{Cd}$ (II) cations increased when the temperature increased. The Langmuir maximum adsorption capacity of FMS ( $Q^{\circ}{ }_{\max } \pm$ standard error) exhibited the increasing order as follows: $18.2 \pm 0.53 \mathrm{mg} / \mathrm{g}$ at $10^{\circ} \mathrm{C}<26.0 \pm 0.73 \mathrm{mg} / \mathrm{g}$ at $30^{\circ} \mathrm{C}<$ $28.6 \pm 1.21 \mathrm{mg} / \mathrm{g}$ at $50^{\circ} \mathrm{C}$. This result proved that the removal of cadmium from the solution by FMS was an endothermic process. According to Sdiri et al. (2012), the increase in adsorption capacity with rising temperature resulted from dissolving more calcite and releasing more bicarbonate ions into solution. Correspondingly, the reaction between $\mathrm{HCO}_{3}{ }^{-}$and $\mathrm{Cd}^{2+}$ ions was significantly improved, which led to the precipitation of otavite $\left(\mathrm{CdCO}_{3}\right)$ on the surface of four naturally geological limestones - containing 97.9-99.6\% $\mathrm{CaCO}_{3}$. Furthermore, in the same experimental condition, the FMS biosorbent $(26.0 \mathrm{mg} / \mathrm{g})$ exhibited a relatively similar maximum adsorption capacity to commercial activated carbon $(31.9 \mathrm{mg} / \mathrm{g})$, suggesting that FMS is a promising and low-cost adsorbent for removing toxic cadmium from water media. Notably, after $\mathrm{Cd}(\mathrm{II})$ adsorption, the solution $\mathrm{pH}$ values in the adsorption isotherm ranged between 6.54 and 6.95 , which is higher than the initial $\mathrm{pH}$ values (approximately 6.0). A weaker $\mathrm{pH}$-buffering capacity was presumably attributed to a lower generation of the hydroxyl group (Equation 6). An identical result was reported elsewhere (Alidoust et al., 2015; Zhou et al., 2017).

Furthermore, the competitive adsorption result of multiple metal ions $\left(C_{\mathrm{o}}=0.2 \mathrm{mmol} / \mathrm{L}\right.$ for each metal) demonstrated that the selectivity sequence $\left(q_{\mathrm{e}} ; \mathrm{mmol} / \mathrm{g}\right)$ of metal cations onto FMS followed $\mathrm{Pb}^{2+}(0.267 \mathrm{mmol} / \mathrm{g})>\mathrm{Cd}^{2+}(0.106 \mathrm{mmol} / \mathrm{g})>\mathrm{Cu}^{2+}(0.055 \mathrm{mmol} / \mathrm{g})>\mathrm{Cr}^{3+}(0.022 \mathrm{mmol} /)>$ $\mathrm{Zn}^{2+}(0.021 \mathrm{mmol} / \mathrm{g})$. The adsorption capacity of FMS toward cadmium significantly declined from $0.206 \mathrm{mmol} / \mathrm{L}$ to $0.106 \mathrm{mmol} / \mathrm{g}$ in the presence of other metal cations. This was due to the strong consumption of the dissolving carbonate ions from FMS to form carbonate precipitates (Köhler et al., 2007; Du et al., 2012).

\subsubsection{Adsorption thermodynamics}

Essentially, the adsorption mechanism (i.e., physical or chemical) can be sensibly interpreted through the study of adsorption thermodynamics. The thermodynamic parameters $\left(\Delta G^{\circ}, \Delta H^{\circ}\right.$, and $\Delta S^{\circ}$ ) can be estimated by the calorimetric measurement (Ferreira et al., 2017) or the van't Hoff approach (Tran et al., 2017). Herein, we applied the latter to calculate the thermodynamic parameters of the $\mathrm{Cd}^{2+}$ adsorption process onto FMS through the following equations:

$$
\Delta G^{o}=-R T \ln K_{C}
$$


The close relationship between $\Delta G^{\circ}$ and $\Delta H^{\circ}$ and $\Delta S^{\circ}$ is described as follows:

$\Delta G^{o}=\Delta H^{0}-T \Delta S^{0}$

The well-known van't Hoff equation is obtained by substituting Eq. 22 into Eq. 21.

$$
\ln K_{C}=\frac{-\Delta H^{o}}{R} x \frac{1}{T}+\frac{\Delta S^{o}}{R}
$$

where $K_{\mathrm{C}}$ is the equilibrium constant (dimensionless); $R$ is the universal gas constant $(8.3144 \mathrm{~J} / \mathrm{mol} \times \mathrm{K})$; and $T$ is the absolute temperature in Kelvin.

The Gibbs energy change $\left(\Delta G^{\circ}\right)$ is directly calculated from Equation 21. Meanwhile, the change in enthalpy $\left(\Delta H^{\circ}\right)$ and the change in entropy $\left(\Delta S^{\circ}\right)$ are determined from the slope and intercept of Equation 23, respectively. Table 3 lists the profiles of thermodynamic parameters. The negative $\Delta G^{\circ}$ values at all investigated temperatures indicate that the adsorption phenomenon occurred spontaneously. As well, the positive $\left(+\Delta S^{\circ}\right)$ value reflects that the organization of $\mathrm{Cd}^{2+}$ ions at the solid/solution interface during the adsorption process becomes more random when the temperature increases.

Table 3. Thermodynamic parameters of the adsorption process of cadmium onto FMS

\begin{tabular}{cccccc}
\hline $\mathbf{T}(\mathbf{K})$ & $\mathbf{K}_{\mathbf{C}}$ & van't Hoff equation & $\Delta \mathbf{G}^{\circ}$ & $\Delta \mathbf{H}^{\circ}$ & $\Delta \mathbf{S}^{\circ}$ \\
\hline 283 & 2042 & $\mathrm{y}=-447 \mathrm{x}+9.22$ & -17.93 & 3.72 & 0.077 \\
303 & 2368 & $\mathrm{R}^{2}=0.936$ & -19.57 & & \\
323 & 2479 & & -20.99 & & \\
\hline
\end{tabular}

Note: $K_{\mathrm{C}}$ values derived from the Langmuir $K_{\mathrm{L}}$ constant; $\Delta G^{\circ}$ and $\Delta H^{\circ}(\mathrm{kJ} / \mathrm{mol}) ;$ and $\Delta S^{\circ}$ $(\mathrm{kJ} / \mathrm{mol} \times \mathrm{K})$.

The equilibrium constant $K_{\mathrm{C}}$ remarkably increased when the temperature rose, which verified that the adsorption process was more favourable at a higher temperature and endothermic in nature. The conclusions matched well with the adsorption isotherm and the entropy change sign. As indicated in Table 2, the Langmuir maximum adsorption capacity increased by approximately $58 \%$ when the solution temperature increased from $10{ }^{\circ} \mathrm{C}$ to $50{ }^{\circ} \mathrm{C}$. A positive value of $\Delta H^{\circ}$ suggests that the adsorption process occurred endothermically. An endothermic process is unequivocally attributed to chemical adsorption (chemisorption) with the existence of strong force. In contrast, physical adsorption arises from relatively weak interactions (i.e., van der Waals force); therefore, the amount of adsorbent adsorbed often tends to easily desorb when temperature increases (exothermic).

Similarly, many investigators stated the endothermic nature of potentially toxic metals adsorption onto geological calcium carbonate (Sdiri et al., 2012), biogenetic aragonite (Hsu 2009; Zhao et al., 2016; Du et al., 2012), and biogenetic calcite (Flores-Cano et al., 2013). Notably, the low magnitude of thermodynamic parameters $-\Delta G^{\circ}$ (from $17.9 \mathrm{~kJ} / \mathrm{mol}$ to $20.9 \mathrm{~kJ} / \mathrm{mol}$ ), $\Delta H^{\circ}$ (3.72 $\mathrm{kJ} / \mathrm{mol})$, and $\Delta S^{\circ}(0.077 \mathrm{~kJ} / \mathrm{mol})$-remained consistent with other scholars' findings (Zhao et al., 2016; Zhou et al., 2017; Du et al., 2012). For example, Du et al. (2012) applied the nano-sized aragonite mollusk shells for $\mathrm{Cd}^{2+}$ removal from aqueous solution, concluding the similar magnitude of $\Delta G^{\circ}$ (from $3.9 \mathrm{~kJ} / \mathrm{mol}$ to $\left.5.3 \mathrm{~kJ} / \mathrm{mol}\right), \Delta H^{\circ}(5.62 \mathrm{~kJ} / \mathrm{mol})$, and $\Delta S^{\circ}(0.034 \mathrm{~J} / \mathrm{mol})$.

\subsubsection{Adsorption reversibility}

To some extent, the adsorption mechanism can be explained through a desorption study. Generally, if cadmium adsorbed onto the FMS surface is easily desorbed by pure water at a low $\mathrm{pH}$ value, the primary adsorption mechanism will involve electrostatic attraction because of the existing weak force in the adsorption process. Similarly, the adsorption mechanism regarding cation exchange and electrostatic attraction can be evaluated through the amount of cadmium desorbed by $\mathrm{HCl}$ solution. Table 4 displays the percentage of $\mathrm{Cd}^{2+}$ ions desorbed using various desorbing agents (i.e., pure water at $\mathrm{pH} 2.0, \mathrm{HCl}, \mathrm{NaCl}$, and $\mathrm{CaCl}_{2}$ ). Clearly, the desorption efficiency decreased when the initial cadmium concentrations increased in the adsorption study because of the effect of driving force or the dissimilar ratio of contributors. Du et al. (2011) also demonstrated that the primary adsorption 
mechanism of divalent metals onto aragonite and calcite mollusk shells was: firstly, ionic exchange and surface complexion at a low metal concentration; and secondly, dissolution-precipitation at a high metal concentration.

Table 4. Percentage of $\mathrm{Cd}^{2+}$ desorbed using various desorbing agents

\begin{tabular}{ccccc}
\hline $\mathbf{C}_{\mathbf{o}}$ & Water $(\mathbf{p H}=\mathbf{2 . 0})$ & HCl $(\mathbf{0 . 1} \mathbf{M})$ & $\mathbf{N a C l}(\mathbf{0 . 1 M})$ & $\mathbf{C a C l}_{\mathbf{2}}(\mathbf{0 . 1} \mathbf{~ M})$ \\
\hline 29.3 & $1.56 \pm 0.07$ & $26.29 \pm 1.21$ & $16.82 \pm 0.72$ & $15.3 \pm 0.55$ \\
49.8 & $0.89 \pm 0.01$ & $14.76 \pm 0.10$ & $7.11 \pm 0.05$ & $12.0 \pm 1.55$ \\
101.6 & $0.51 \pm 0.01$ & $1.90 \pm 0.04$ & $6.93 \pm 1.27$ & $5.91 \pm 0.22$ \\
154.2 & $0.34 \pm 0.11$ & $0.60 \pm 0.02$ & $3.29 \pm 0.13$ & $4.11 \pm 2.27$ \\
192.9 & $0.33 \pm 0.02$ & $0.36 \pm 0.02$ & $3.03 \pm 0.15$ & $4.15 \pm 0.09$ \\
\hline
\end{tabular}

Note: $C_{\mathrm{o}}$ means the initial $\mathrm{Cd}^{2+}$ concentration in the adsorption study.

Generally, the desorption efficiency was relatively lower than what was expected. Therefore, it can be concluded that the cadmium adsorption onto FMS was a highly irreversible process when a strong chemical interaction was evident (Cooney, 1998). Similarly, Flores-Cano et al. (2013) proposed that the cadmium adsorption on chicken eggshells-originated biosorbent occurred through irreversible (surface precipitation in the $(\mathrm{Cd}, \mathrm{Ca}) \mathrm{CO}_{3}$ formation; approximately $68 \%$ ) and reversible (cation exchange between $\mathrm{Ca}^{2+}$ and $\mathrm{Cd}^{2+}$ ions; approximately 32\%) mechanisms. Baláž et al. (2016) also concluded that the percentage of cadmium desorbed from the surface of laden eggshells was only $6.28 \%$, suggesting that it is an irreversible process.

In contrast, Zhou et al. (2017) concluded that approximately $97 \%$ of adsorbed cadmium onto crab shells can be recovered with a $0.1 \mathrm{M} \mathrm{HNO}_{3}$ solution. This is because raw crab shells contain high protein content (40\%), calcium carbonate (30\%), chitin (20-25\%), lipid, and pigments. Therefore, they asserted that the primary adsorption mechanism was cation exchange (with $\mathrm{Ca}$ and $\mathrm{Mg}$ ), chelation, and precipitation in the potential forms of $(\mathrm{Cd}, \mathrm{Ca}) \mathrm{CO}_{3}$ and $\mathrm{CdCO}_{3}$.

The adsorption process was highly irreversible because the adsorption mechanism was surface precipitation. Therefore, the leaching of metal from metal-laden adsorbent into the environment seems negligible. In the future study, the leaching test for exhausted FMS will be carried out to confirm this hypothesis. In case of high concentration of toxic elements is found in the leaching test, the encapsulation of sludge cake through solidification/stabilization techniques can be a solution for sludge management. Here, the recovery and reuse of sludge cakes seems to be impractical due to the high treatment cost. The market for the recovered materials is limited if low treatment cost is applied due to the impurity of the recovered materials.

\subsection{Adsorption performance in column experiments}

Figure 6d illustrates an experimental setup for breakthrough curve determination. The breakthrough curves and operation parameters for cadmium adsorption onto FMS are shown in Figure 6 and Table 5, respectively. The breakthrough curves exhibited a typically relative smooth $S$-shaped profile, which is often controlled by the shape and length of the mass transfer zone. 

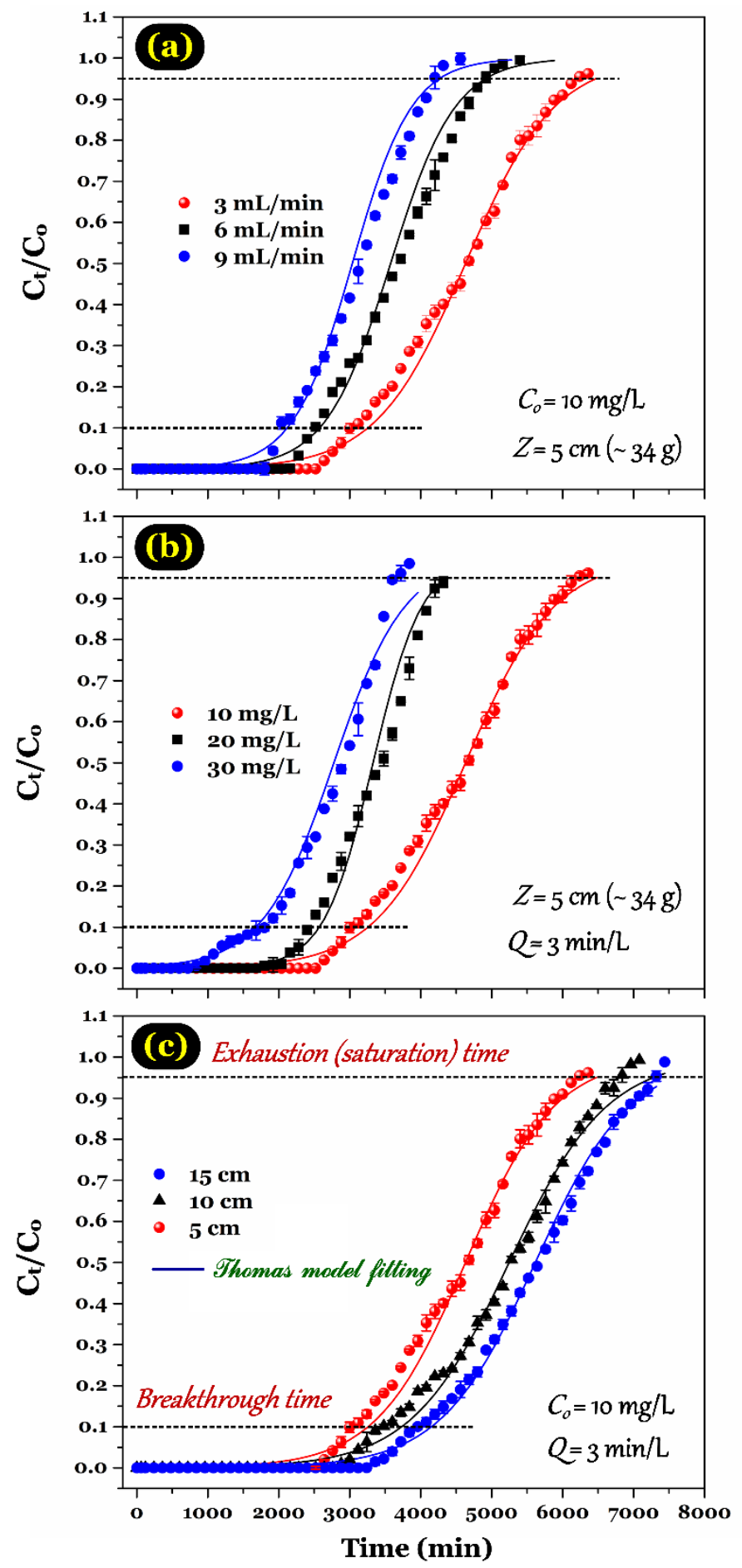

Figure 6. Breakthrough curves for different (a) flow rates, (b) feed concentrations, and (c) bed heights $\left(\mathrm{pH}=6.0\right.$ and room temperature $\left.=30 \pm 3.0^{\circ} \mathrm{C}\right)$

To examine the breakthrough profiles in the fixed-bed adsorption process, various mathematical models were applied to describe the dynamic adsorption behaviour of cadmium in the fixed-bed column, such as the Thomas, Adams-Bohart, and Yoon-Nelson models. In this study, we applied only the Thomas model for predicting the adsorption curve of breakthrough in the fixed-bed reactor to determine the highest adsorption capacity of FMS under various operational conditions. The nonlinear and linear forms of the Thomas model are described in Equations 24 and 25, respectively. The Thomas linear plot is $\ln \left(\left(C_{o} / C_{t}\right)-1\right)$ versus $t$. 


$$
\begin{aligned}
& \frac{C_{t}}{C_{o}}=\frac{1}{1+\exp \left(k_{T H} q_{o} \frac{m_{3}}{Q}-k_{T H} C_{o} t\right)} \\
& \ln \left(\frac{C_{o}}{C_{t}}-1\right)=k_{T H} q_{o} \frac{m_{3}}{Q}-k_{T H} C_{o} t
\end{aligned}
$$

where $k_{T H}(\mathrm{~mL} / \mathrm{min} \times \mathrm{mg})$ is the Thomas adsorption rate constant; $q_{o}(\mathrm{mg} / \mathrm{g})$ is the column maximum equilibrium cadmium uptake per gram of FMS; $m_{3}(\mathrm{~g})$ is the mass of FMS used in the column; and $Q$ $(\mathrm{mL} / \mathrm{min})$ is the volumetric flow rate.

\subsubsection{Effect of flow rate}

The influence of volumetric flow rate $(Q ; \mathrm{mL} / \mathrm{min})$ on the FMS adsorption capacity, breakthrough time, and exhaustion time is illustrated in Figure 6a. The breakthrough and exhaustion times (Table 5) proportionally decreased with increasing flow rate from 3 to $9 \mathrm{~mL} / \mathrm{min}$. This result is consistent with the adsorption rates $\left(k_{\mathrm{TH}}\right)$ of the Thomas model (Table 5), which means a higher flow rate causing a faster saturation rate.

Table 5. Parameters of cadmium adsorption onto the FMS biosorbent in the fixed-bed column at

\begin{tabular}{|c|c|c|c|c|c|c|c|c|c|c|c|}
\hline \multicolumn{3}{|c|}{ Operation condition } & \multicolumn{4}{|c|}{ Thomas constant } & \multicolumn{5}{|c|}{ Adsorption column parameters } \\
\hline $\mathbf{Q}$ & $\mathrm{C}_{\mathrm{o}}$ & $\mathbf{Z}$ & $\mathbf{k}_{\mathrm{TH}}$ & $\mathbf{q}_{\mathrm{o}}$ & $\mathbf{R}^{2}$ & $\mathbf{X}^{2}$ & $\mathbf{T}_{\mathrm{b}}$ & Ts & WHO & $\mathbf{q}_{\mathbf{b}}$ & $\mathbf{q}_{\mathrm{s}}$ \\
\hline 3 & 10 & 5 & 0.160 & 4.10 & 0.957 & 0.58 & 3060 & 5820 & 2820 & 2.70 & 5.11 \\
\hline 6 & 10 & 5 & 0.220 & 5.89 & 0.981 & 0.87 & 2580 & 4860 & 2280 & 4.55 & 8.54 \\
\hline 9 & 10 & 5 & 0.240 & 7.86 & 0.965 & 0.15 & 2115 & 4170 & 1680 & 5.60 & 10.9 \\
\hline 3 & 20 & 5 & 0.135 & 5.93 & 0.970 & 0.16 & 2430 & 4350 & 2100 & 4.29 & 7.64 \\
\hline 3 & 30 & 5 & 0.073 & 7.21 & 0.953 & 0.23 & 1680 & 3630 & 930 & 4.44 & 9.56 \\
\hline 3 & 10 & 10 & 0.080 & 4.21 & 0.924 & 0.53 & 3480 & 6750 & 2940 & 3.07 & 5.93 \\
\hline 3 & 10 & 15 & 0.073 & 4.57 & 0.913 & 0.76 & 3960 & 7230 & 3540 & 3.49 & 6.35 \\
\hline
\end{tabular}
different operating conditions

Note: the unit of $Q$ (follow rate; $\mathrm{mL} / \mathrm{min}$ ), $C_{\mathrm{o}}$ (initial $\mathrm{Cd}$ concentration; $\mathrm{mg} / \mathrm{L}$ ), $Z$ (bed height; $\mathrm{cm}$ ), and $k_{\mathrm{TH}}($ the Thomas rate constant; $10^{-3} \mathrm{~mL} / \mathrm{min} \times \mathrm{mg}$ ), $q_{\mathrm{o}}$ (the Thomas adsorption capacity; $\mathrm{mg} / \mathrm{g}$ ), $T_{\mathrm{b}}$ (breakthrough time; $\min$ ), $T_{\mathrm{s}}$ (saturation time; $\min$ ), WHO (the time when the effluent cadmium concentration will be higher than $0.003 \mathrm{mg} / \mathrm{L} ; \mathrm{min}$ ), $q_{\mathrm{b}}$ (breakthrough capacity; $\mathrm{mg} / \mathrm{g}$ ), $q_{\mathrm{s}}$ (saturation capacity; $\mathrm{mg} / \mathrm{g}$ ).

In general, the adsorption capacity of adsorbent often decreases when flow rate increases because of the insufficient residence time between adsorbent and adsorbate (Vilvanathan and Shanthakumar, 2017; Chao et al., 2014). For instance, Chao et al. (2014) explored the biosorption of potentially toxic metals $\left(\mathrm{Cu}^{2+}, \mathrm{Cd}^{2+}, \mathrm{Ni}^{2+}\right.$, and $\left.\mathrm{Pb}^{2+}\right)$ on citrus maxima peel, passion fruit shell, and sugarcane bagasse in a continuous fixed-bed column. The authors found that the Thomas maximum adsorption capacity $\left(q_{\mathrm{o}} ; \mathrm{mg} / \mathrm{g}\right)$ of such lignocellulosic wastes-derived biosorbents to selective cation metals significantly decreased when the flow rate increased from 2.0 to $3.0 \mathrm{~mL} / \mathrm{min}$ and then 4.0 $\mathrm{mL} / \mathrm{min}$. This is because ion exchange and complexation were regarded as the primary mechanism.

Therefore, the highest amount of cadmium adsorbed onto FMS was expected to occur at the lowest flow rate of $3 \mathrm{~mL} / \mathrm{min}$. However, as indicated in Table 5, the Thomas adsorption capacity of FMS significantly increased from $4.10 \mathrm{mg} / \mathrm{g}$ to $7.21 \mathrm{mg} / \mathrm{g}$ when the flow rate rose from $3 \mathrm{~mL} / \mathrm{min}$ to $9 \mathrm{~mL} / \mathrm{min}$. This is because the surface precipitation occurred faster than the others (i.e., cation exchange), which is consistent with the result in the batch adsorption kinetics study. Furthermore, the shape of the breakthrough curve at 3,6, and $9 \mathrm{~mL} / \mathrm{min}$ is relatively similar (Figure 6a), suggesting that the adsorption process can still reach adsorption equilibrium at the highest flow rate of $9 \mathrm{~mL} / \mathrm{min}$. Similarly, Lim and Aris (2014) used the dead calcareous skeletons-based biosorbent to remove 
cadmium ions from water solution under the continuous fixed-bed column study. They also reported that the $q_{\mathrm{o}}$ values increased with an elevation in flow rate as follows: $17.7 \mathrm{mg} / \mathrm{g}$ at $10 \mathrm{~mL} / \mathrm{min}<41.6$ $\mathrm{mg} / \mathrm{g}$ at $15 \mathrm{~mL} / \mathrm{min}<66.2 \mathrm{mg} / \mathrm{g}$ at $20 \mathrm{~mL} / \mathrm{min}$. However, this result differs from that of Zhang et al. (2017) when referring to the removal of potentially toxic cation metals $\left(\mathrm{Cd}^{2+}, \mathrm{Pb}^{2+}\right.$ and $\left.\mathrm{Cu}^{2+}\right)$ from acid mine drainage using biosorbent chicken eggshells.

\subsubsection{Effect of initial cadmium concentration}

Figure $6 \mathrm{~b}$ displays the time dependence on the breakthrough curve at varying cadmium concentrations in the influent $(10,20$, and $30 \mathrm{mg} / \mathrm{L})$. The cadmium breakthrough time dramatically fell (from $3060 \mathrm{~min}$ to $2430 \mathrm{~min}$ and then to $1680 \mathrm{~min}$ ) when the feed cadmium concentration increased from 10 to 20 and then to $30 \mathrm{mg} / \mathrm{L}$, respectively. This means that the bed became more quickly saturated when more cadmium ions were introduced to the FMS column (Lim and Aris, 2014). In contrast, the maximum cadmium adsorption capacity decreased within an appreciable increase in inlet cadmium ion concentration. The Thomas adsorption capacity of FMS was ranked in the following order: $4.10 \mathrm{mg} / \mathrm{g}$ at $10 \mathrm{mg} / \mathrm{L}<5.63 \mathrm{mg} / \mathrm{g}$ at $20 \mathrm{mg} / \mathrm{L}<7.21 \mathrm{mg} / \mathrm{g}$ at $30 \mathrm{mg} / \mathrm{L}$. A higher initial cadmium concentration led to a larger amount of cadmium being adsorbed onto FMS because of a greater driving force on the FMS surface (Vilvanathan and Shanthakumar, 2017).

\subsubsection{Effect of bed height}

The effect of various bed heights $(5,10$, and $15 \mathrm{~cm})$ on the breakthrough curve at a solution flow rate $(3 \mathrm{~mL} / \mathrm{min})$ and feed concentration $(10 \mathrm{mg} / \mathrm{L})$ is presented in Figure $6 \mathrm{c}$. The breakthrough and exhaustion times (Table 5) dramatically increased from $3060 \mathrm{~min}$ to $3960 \mathrm{~min}$ and from $5820 \mathrm{~min}$ to $7230 \mathrm{~min}$ when the bed height increased from $5 \mathrm{~cm}$ to $15 \mathrm{~cm}$, respectively. Compared with the other operations (i.e., flow rate and initial $\mathrm{Cd}$ concentration), the bed height wielded less impact on the maximum column adsorption capacity. The Thomas adsorption capacity of FMS only ranged from $4.10 \mathrm{mg} / \mathrm{g}$ to $4.57 \mathrm{mg} / \mathrm{g}$ within the change of bed heights $(5,10$, and $15 \mathrm{~cm})$. An analogous observation was recognized by other scholars (Zhang et al., 2017; Li and Champagne, 2009). They found that the $q_{\mathrm{o}}$ values of cadmium adsorption onto chicken eggshells were $1.13 \mathrm{mg} / \mathrm{g}$ at $10 \mathrm{~cm}, 1.85 \mathrm{mg} / \mathrm{g}$ at 20 $\mathrm{cm}$, and $1.63 \mathrm{mg} / \mathrm{g}$ at $30 \mathrm{~cm}$ (Zhang et al., 2017).

\subsection{Discussion of a plausible adsorption mechanism}

The adsorption mechanism of potentially toxic metals (i.e., cadmium) onto carbonate-rich materials has been reported in the literature, including: (1) pore filling, (2) electrostatic attraction (outsphere complexes), (3) non-electrostatic attraction (inner-sphere complexation), (4) surface precipitation in forms of $\mathrm{Cd}(\mathrm{OH})_{2},(\mathrm{Ca}, \mathrm{Cd}) \mathrm{CO}_{3}, \mathrm{Cd}_{3}\left(\mathrm{CO}_{3}\right)_{2}(\mathrm{OH})_{2}$, and $\mathrm{CdCO}_{3}$, and (5) cation exchange with alkali metals $\left(\mathrm{K}^{+}\right.$and $\left.\mathrm{Na}^{+}\right)$and alkaline earth metals $\left(\mathrm{Ca}^{2+}\right.$ and $\mathrm{Mg}^{2+}$ ) (Prieto et al., 2003; Alidoust et al., 2015; Lim and Aris, 2014; Kuh and Kim, 2000).

As previously discussed, the FMS adsorbent exhibited a low $S_{\mathrm{BET}}$ value $\left(1.449 \mathrm{~m}^{2} / \mathrm{g}\right)$, suggesting that pore filling makes a nominal contribution to the adsorption mechanism. Moreover, the analyses on the effects of $\mathrm{pH}$ (Section 3.2.1) and desorption (Section 3.2.6) demonstrated that electrostatic and non-electrostatic attractions played an auxiliary role in binding $\mathrm{Cd}$ (II) cations in the solution. Furthermore, the analysis of FTIR (Figure 4) indicated that the peaks regarding the carbonyl $(\mathrm{C}=\mathrm{O})$ group did not significantly decrease in intensity or shift toward higher/lower wavenumbers after cadmium adsorption. It is suggested here that complexation played an unimportant role ( $\underline{\text { Zhao et }}$ al., 2016; Lim and Aris, 2014).

Furthermore, the bulk precipitation of hexagonal crystals of $\mathrm{Cd}(\mathrm{OH})_{2}$ has been identified as a predominant mechanism of cadmium adsorption onto calcined oyster shell fragments (Alidoust et al., 2015). They reported that the $\mathrm{Cd}(\mathrm{OH})_{2}$ crystalline on the surface of calcined oyster shells was mainly identified at 2-Theta of approximately $19^{\circ}, 35^{\circ}, 48^{\circ}$, and $52^{\circ}$. However, the precipitation of $\mathrm{Cd}(\mathrm{OH})_{2}$ was ruled out in this study, which is very consistent with the XRD result (absence of diffraction peaks observed for cadmium hydroxide). Cadmium will be precipitated as $\mathrm{Cd}(\mathrm{OH})_{2}$ in an 
alkaline medium ( $\mathrm{pH}_{\text {soultion }}>$ 8.5) (Veneu et al., 2017; Guo et al., 2015). The finial $\mathrm{pH}_{\text {solution }}$ in this study ranged from 6.13 to 7.33 , confirming that the adsorption mechanism did not involve the precipitation of cadmium with hydroxide. This finding is similar to that presented by Veneu et al. (2017) for Cd(II) adsorption onto algae Lithothamnium calcareum, but dissimilar to Alidoust et al. (2015) for $\mathrm{Cd}(\mathrm{II})$ adsorption onto calcined oyster shells.

In essential, cation exchange is known as a reversible process. If cation exchange between $\mathrm{Cd}^{2+}$ ions and exchangeable cations (i.e., $\mathrm{Ca}^{2+}$ ) in solution dominates, then cadmium desorption efficiency from the FMS surface using $\mathrm{NaCl}$ and $\mathrm{CaCl}_{2}$ should be excellent (Flores-Cano et al., 2013). This is because of the ionic radii similarity between cadmium $(0.095 \mathrm{~nm})$ and calcium $(0.10 \mathrm{~nm})$, and $\mathrm{Cd}$ (II) will substitute for $\mathrm{Ca}$ (II) at the accessible surface sites of FMS. This process has been also known as the isomorphic substitution mechanism (Alidoust et al., 2015; Veneu et al., 2017). However, the desorption study (Section 3.2.6) demonstrated that the desorption efficiency was only approximately $15 \%$, suggesting that cation exchange was an integral part of the adsorption mechanism, but not a predominant one. Such inference tallies with the EDS result before and after adsorption (Figure 3). A slight decrease in the percentage of $\mathrm{Ca}$ element after adsorption confirmed again that the cation exchange between guest cadmium (in the solution) and host calcium (in the aragonite) was not the primary adsorption mechanism. In addition, the XRD data (Figure 1) demonstrated that the content of $\mathrm{CaCO}_{3}$ slightly decreased by approximately $5 \%$ (from $90.8 \%$ to $86.2 \%$ ) after cadmium adsorption. The result also confirmed that ion exchange played an integral role in removing $\mathrm{Cd}$ (II) from the solution, but not primary adsorption mechanism. Similarly, Alidoust et al. (2015) compared the $\mathrm{Cd}(\mathrm{II})$ adsorption capacity onto pristine and calcined oyster shells, finding that the $\mathrm{CaCO}_{3}$ in pristine oyster shells was completely converted to pure $\mathrm{CaO}$ at a calcination temperature of $900{ }^{\circ} \mathrm{C}$ (the starting temperature of calcite conversion into calcium oxide was $650{ }^{\circ} \mathrm{C}$ ). They concluded that cadmium adsorption through an ion-exchange mechanism with $\mathrm{Ca}^{2+}$ is more efficacious in a $\mathrm{CaO}$ system (calcined oyster shells) than in a calcite system (pristine oyster shells).

Another adsorption mechanism of cadmium onto $\mathrm{CaCO}_{3}$-enriched adsorbent with much potential was the surface precipitation in two distinct forms, specifically $(\mathrm{Cd}, \mathrm{Ca}) \mathrm{CO}_{3}$ (Flores-Cano et al., 2013; Du et al., 2011; Prieto et al., 2003; Tran et al., 2016) and $\mathrm{CdCO}_{3}$ (Veneu et al., 2017; Köhler et al., 2007; Li et al., 2014). For example, Prieto et al. (Prieto et al. 2003) wrote that cadmi um could be incorporated onto the biogenic and abiogenic aragonites by the surface precipitation of $(\mathrm{Cd}$, $\mathrm{Ca}) \mathrm{CO}_{3}$ solid solution with a calcite-type structure. Meanwhile, Köhler et al. 2007 (2007) applied the biogenic aragonite material (cockleshells) to remove $\mathrm{Cd}^{2+}$ ions from aqueous solution, emphasizing that the primary adsorption mechanism was the surface precipitation of white otavite crystallite $\left(\mathrm{CdCO}_{3}\right)$. The SEM image of Cd-laden FMS (Figure 2b) demonstrated an overgrowth of rhombohedral crystals on the FMS surface.

Meanwhile, the EDS of Cd-laden FMS (Figure 3b) indicates that the main elements in the crystals were $\mathrm{C}, \mathrm{O}, \mathrm{Ca}$, and $\mathrm{Cd}$, which means that $\mathrm{Ca}$ still remains on the FMS surface after $\mathrm{Cd}$ adsorption. The results suggested that cadmium can readily be incorporated in the $\mathrm{CaCO}_{3}$ structure to form the $(\mathrm{Cd}, \mathrm{Ca}) \mathrm{CO}_{3}$ precipitates on the FMS surface. Notably, Prieto et al. $(\underline{2003})$ concluded that after a prolonged reaction time between cadmium and the abiogenic aragonite, the substrate became completely covered by rhombohedral crystals that form a crust on the aragonite's surface. This phenomenon is similar to the morphology observed in our study (Figure 5c) and those of other researchers (Köhler et al., 2007). That is, the cockleshells become completely covered by a crust of $(\mathrm{Cd}, \mathrm{Ca}) \mathrm{CO}_{3}$ precipitate after cadmium adsorption. Furthermore, some new prominent peaks appeared in the XRD spectrum (Figure 1b) after adsorption, indicating the appearance of a new mineral solid phase after the carbonate recrystallization process in the otavite form (Veneu et al., 2017). According to the XRD pattern (Figure 1b), the precipitate as $\mathrm{CdCO}_{3}$ otavite crystals was identified at angles of $26.27^{\circ}, 31.14^{\circ}, 40.08^{\circ}, 43.67^{\circ}, 49.87^{\circ}, 52.92^{\circ}$, and $61.81^{\circ}$, which is in accordance with the literature (Veneu et al., 2017; Li et al., 2014). Namely, Veneu et al. (2017) found that the diffractogram obtained 
from Lithothamnium calcareum algae after cadmium adsorption demonstrated the typically characteristic otavite phase peaks, at $2 \theta=27.23^{\circ}, 35.28^{\circ}, 42.30^{\circ}, 51.13^{\circ}, 58.47^{\circ}, 68.46^{\circ}, 72.84^{\circ}$ and $77.54^{\circ}$.

Notably, chemisorption is often divided two categories (activated chemisorption and nonactivated chemisorption) that are strongly dependent on the magnitude of activation energy (Ea) and adsorption rate. Activated chemisorption usually occurs slowly and requires a significant activation energy (often higher than $40 \mathrm{~kJ} / \mathrm{mol}$ ). In contrast, non-activated chemisorption often occurs very rapidly even at a very low temperature and has an insignificant activation energy, i.e. nearly zero (Ghosh, 2009; Hill and Root, 2014). According to the kinetic study, the adsorption process occurred very rapidly even at $10^{\circ} \mathrm{C}$ (Figure 5), but the negligible magnitude of activation energy was calculated as $10.2 \mathrm{~kJ} / \mathrm{mol}$ (using the Arrhenius equation), which is a signal of non-activated chemisorption. Nonactivated chemisorption was also reported by Guo et al. (2015) for the adsorption of cadmium onto succinic anhydride-modified maize straw sample. They concluded that a low magnitude of Ea $(4.7 \mathrm{~kJ} / \mathrm{mol}$ ) confirmed that the energy barrier (or potential barrier) against the adsorption of cadmium ions is easier to overcome; therefore, the adsorption process occurred very rapidly. Notably, Cubillas et al. (2005) concluded that the Ea values of otavite $\left(\mathrm{CdCO}_{3}\right)$ precipitation ranged from $5.55 \mathrm{~kJ} / \mathrm{mol}$ to $8.60 \mathrm{~kJ} / \mathrm{mol}$ for the cadmium adsorption onto aragonite, calcite, cockle shells, clam shells, and mussel shells.

Tables 6-7 summarizes a comparison of adsorption efficiency of FMS and other adsorbents in the literature under batch and column technique, respectively. According to the table, the FMS adsorbent exhibited a relatively high affinity to cadmium in both batch and column experiments. Therefore, the freshwater mussel shells are a promising adsorbent for a large-scale application in removing cadmium from water environments.

Table 6. Comparison of Langmuir maximum adsorption capacity ( $Q^{\circ}$ max; $\mathrm{mg} / \mathrm{g}$ ) of FMS toward cadmium in this study and other adsorbents in the literature

\begin{tabular}{|c|c|c|c|c|}
\hline Adsorbent & Polymorph & Experimental condition & $\begin{array}{c}Q^{\mathbf{0}} \max \\
(\mathrm{mg} / \mathrm{g})\end{array}$ & Reference \\
\hline Modified maize straw & - & $1 \mathrm{~g} / \mathrm{L}, 20^{\circ} \mathrm{C}, 1.5 \mathrm{~h}, \mathrm{pH} 5.8$ & 196 & Guo et al. 2015 \\
\hline Coral Strands & $\begin{array}{l}\text { Aragonite, } \\
\text { Calcite }\end{array}$ & $1 \mathrm{~g} / \mathrm{L}, 25^{\circ} \mathrm{C}, 1 \mathrm{~h}, \mathrm{pH} 5.0$ & 189 & $\underline{\text { Veneu et al. } 2017}$ \\
\hline Orange peel biochar & - & $2 \mathrm{~g} / \mathrm{L}, 30^{\circ} \mathrm{C}, 24 \mathrm{~h}, \mathrm{pH} 7.0$ & 115 & $\underline{\text { Tran et al. } 2016}$ \\
\hline Apple snail shell & Aragonite & $2 \mathrm{~g} / \mathrm{L}, 30^{\circ} \mathrm{C}, 1 \mathrm{~h}, \mathrm{pH} 3.5$ & 81.3 & Zhao et al. 2016 \\
\hline Commercial AC & - & $4 \mathrm{~g} / \mathrm{L}, 30^{\circ} \mathrm{C}, 2 \mathrm{~h}, \mathrm{pH} 6.0$ & 31.9 & This study \\
\hline Cantaloupe peel & - & $5 \mathrm{~g} / \mathrm{L}, 30^{\circ} \mathrm{C}, 24 \mathrm{~h}, \mathrm{pH} 5.0$ & 30.4 & Tran and Chao 2018 \\
\hline Oyster shell & Calcite & $4 \mathrm{~g} / \mathrm{L}, 25^{\circ} \mathrm{C}, 96 \mathrm{~h}, \mathrm{pH}(\mathrm{NA})$ & 29.5 & $\underline{\text { Alidoust et al. } 2015}$ \\
\hline Mussel shells (FMS) & Aragonite & $4 \mathrm{~g} / \mathrm{L}, 30^{\circ} \mathrm{C}, 2 \mathrm{~h}, \mathrm{pH} 6.0$ & 26.0 & This study \\
\hline Eggshells & Calcite & $1 \mathrm{~g} / \mathrm{L}, 25^{\circ} \mathrm{C}, 6 \mathrm{~h}, \mathrm{pH} 7.0$ & 23.4 & Baláž et al. 2016 \\
\hline Commercial AC & - & $12 \mathrm{~g} / \mathrm{L}, 25^{\circ} \mathrm{C}, 1 \mathrm{~h}, \mathrm{pH} 5.0$ & 18.0 & $\overline{\text { Coelho et al. } 2014}$ \\
\hline Pine cone & - & $5 \mathrm{~g} / \mathrm{L}, 30^{\circ} \mathrm{C}, 24 \mathrm{~h}, \mathrm{pH} 5.0$ & 17.3 & Tran and Chao 2018 \\
\hline Litchi fruit peel & - & $5 \mathrm{~g} / \mathrm{L}, 30^{\circ} \mathrm{C}, 24 \mathrm{~h}, \mathrm{pH} 5.0$ & 11.5 & $\overline{\text { Tran and Chao } 2018}$ \\
\hline Cashew nut shell & - & $12 \mathrm{~g} / \mathrm{L}, 25^{\circ} \mathrm{C}, 1 \mathrm{~h}, \mathrm{pH} 5.0$ & 11.2 & Coelho et al. 2014 \\
\hline Annona squamosa peel & - & $5 \mathrm{~g} / \mathrm{L}, 30^{\circ} \mathrm{C}, 24 \mathrm{~h}, \mathrm{pH} 5.0$ & 7.40 & Tran and Chao 2018 \\
\hline Bamboo shoot & - & $5 \mathrm{~g} / \mathrm{L}, 30^{\circ} \mathrm{C}, 24 \mathrm{~h}, \mathrm{pH} 5.0$ & 7.03 & Tran and Chao 2018 \\
\hline Sugarcane bagasse & - & $5 \mathrm{~g} / \mathrm{L}, 30^{\circ} \mathrm{C}, 24 \mathrm{~h}, \mathrm{pH} 5.0$ & 6.13 & Tran and Chao 2018 \\
\hline Corbicula fluminea shell & Aragonite & $5 \mathrm{~g} / \mathrm{L}, 25^{\circ} \mathrm{C}, 24 \mathrm{~h}, \mathrm{pH} 7.0$ & 4.03 & Ismail et al. 2014 \\
\hline Chicken eggshell & Calcite & $5 \mathrm{~g} / \mathrm{L}, 25^{\circ} \mathrm{C}, 4 \mathrm{~d}, \mathrm{pH} 6.0$ & 3.75 & $\underline{\text { Flores-Cano et al. }}$ \\
\hline Crab shell & $\begin{array}{c}\mathrm{CaCO}_{3} \\
(\sim 30 \%)\end{array}$ & $0.4 \mathrm{~g} / \mathrm{L}, 25^{\circ} \mathrm{C}, 24 \mathrm{~h}, \mathrm{pH} 5.5$ & 3.43 & Zhou et al. 2017 \\
\hline
\end{tabular}




\begin{tabular}{|c|c|c|c|c|}
\hline Razor clam shell & Aragonite & $0.5 \mathrm{~g} / \mathrm{L}, 25{ }^{\circ} \mathrm{C}, 24 \mathrm{~h}, \mathrm{pH} 5.0$ & 0.45 & $\underline{\text { Du et al. } 2011}$ \\
\hline Eggshells & Calcite & $25 \mathrm{~g} / \mathrm{L}, 25^{\circ} \mathrm{C}, 24 \mathrm{~h}, \mathrm{pH} 5.5$ & 0.51 & Ahmad et al. 2012 \\
\hline Oyster shell & Calcite & $0.5 \mathrm{~g} / \mathrm{L}, 25^{\circ} \mathrm{C}, 24 \mathrm{~h}, \mathrm{pH} 5.0$ & 0.17 & Du et al. 2011 \\
\hline Coral waste & Calcite & $25 \mathrm{~g} / \mathrm{L}, 25^{\circ} \mathrm{C}, 24 \mathrm{~h}, \mathrm{pH} 5.5$ & 0.12 & Ahmad et al. 2012 \\
\hline \multicolumn{5}{|c|}{$\begin{array}{l}\text { NOTE: NA (not adjusted); AC (activated carbon) } \\
\text { Table } 7 \cdot \text { Comparison of Thomas maximum adsorption capacity }\left(q_{\mathrm{o}} ; \mathrm{mg} / \mathrm{g}\right) \text { of FMS toward cadmium } \\
\text { in this study and other adsorbents in the literature }\end{array}$} \\
\hline Adsorbent & Polymorph & Experimental conditions & $\begin{array}{c}\mathbf{q}_{\mathbf{o}} \\
(\mathrm{mg} / \mathrm{g})\end{array}$ & Reference \\
\hline Citrus maxima peel & - & $2 \mathrm{~mL} / \mathrm{min}, 300 \mathrm{mg} / \mathrm{L}, 3 \mathrm{~cm}$ & 132 & Chao et al. 2014 \\
\hline Coral strands & $\begin{array}{c}\text { Aragonite, } \\
\text { Calcite }\end{array}$ & $25 \mathrm{~mL} / \mathrm{min}, 100 \mathrm{mg} / \mathrm{L}, 5 \mathrm{~cm}$ & 124 & $\underline{\text { Veneu et al. } 2017}$ \\
\hline $\begin{array}{l}\text { Calcareous } \\
\text { skeletons }\end{array}$ & $\begin{array}{l}\text { Aragonite, } \\
\text { Calcite }\end{array}$ & $\begin{array}{l}20 \mathrm{~mL} / \mathrm{min}, 100 \mathrm{mg} / \mathrm{L}, 1.10 \\
\mathrm{~cm}\end{array}$ & 66.2 & $\underline{\text { Lim and Aris } 2014}$ \\
\hline Passion fruit shell & - & $2 \mathrm{~mL} / \mathrm{min}, 300 \mathrm{mg} / \mathrm{L}, 3 \mathrm{~cm}$ & 48.6 & Chao et al. 2014 \\
\hline Sugarcane bagasse & - & $2 \mathrm{~mL} / \mathrm{min}, 300 \mathrm{mg} / \mathrm{L}, 3 \mathrm{~cm}$ & 26.3 & Chao et al. 2014 \\
\hline Peat & - & $1.5 \mathrm{~mL} / \mathrm{min}, 209 \mathrm{mg} / \mathrm{L}, 10 \mathrm{~cm}$ & 8.15 & $\begin{array}{l}\text { Li and Champagne } \\
\underline{2009}\end{array}$ \\
\hline Mussel shells (FMS) & Aragonite & $9 \mathrm{~mL} / \mathrm{min}, 10 \mathrm{mg} / \mathrm{L}, 5 \mathrm{~cm}$ & 7.86 & $\overline{\text { This study }}$ \\
\hline Chicken eggshells & Calcite & $10 \mathrm{~mL} / \mathrm{min}, 0.4 \mathrm{mg} / \mathrm{L}, 20 \mathrm{~cm}$ & 1.85 & Zhang et al. 2017 \\
\hline Mollusk shells & Aragonite & $1.5 \mathrm{~mL} / \mathrm{min}, 209 \mathrm{mg} / \mathrm{L}, 15 \mathrm{~cm}$ & 1.69 & $\underline{\text { Li and Champagne }}$ \\
\hline
\end{tabular}

\section{Conclusions}

Characteristics and mechanisms of cadmium adsorption onto biogenic aragonite-based biosorbent (freshwater mussel shells) were investigated in batch and column techniques. The results demonstrated that the optimal solution $\mathrm{pH}$ was higher than 4.0. The adsorption capacity of FMS depended strongly on ionic strength. The kinetic study indicated a fast adsorption equilibrium at approximately $60 \mathrm{~min}$ and a removal rate of approximately $40 \%$ can be achieved within 5 min of contact. The Langmuir maximum cadmium adsorption capacity was $31.94 \mathrm{mg} / \mathrm{g}$ for commercial AC and $26.01 \mathrm{mg} / \mathrm{g}$ for FMS. The Thomas cadmium adsorption capacity of FMS ranged from $4.10 \mathrm{mg} / \mathrm{g}$ to $7.86 \mathrm{mg} / \mathrm{g}$. The adsorption process occurred spontaneously $\left(\Delta G^{\circ}\right)$ and endothermically $\left(\Delta H^{\circ}\right)$. The primary adsorption mechanism was surface precipitation. The toxic cadmium can react with $\mathrm{CaCO}_{3}$ (available in the FMS structure) to form the precipitant of $(\mathrm{Cd}, \mathrm{Ca}) \mathrm{CO}_{3}$ and $\mathrm{CdCO}_{3}$ on the surface of FMS, thus immobilizing cadmium in the solution. Not only was the precipitation process irreversible, the adsorption process was characterized by non-activated chemisorption with a low magnitude of activation energy $(10.2 \mathrm{~kJ} / \mathrm{mol})$. Coexisting metals displayed the relative adsorption selectivity of $\mathrm{Pb}^{2+}$ $>\mathrm{Cd}^{2+}>\mathrm{Cu}^{2+}>\mathrm{Cr}^{3+}>\mathrm{Zn}^{2+}$. It was experimentally concluded that the freshwater mussel shells can serve as a promising low-cost material for removing cadmium in water treatment strategies.

\section{Acknowledgement}

This work was financially supported by the Program of Development in the field of Physics by 2020 (Grant Number: ĐTĐLCN.35/18).

\section{References}

Pourret, O. and Bollinger, J.-C., 2018. "Heavy metal" - What to do now: To use or not to use? Sci. Total Environ. 610-611, 419-420.

Liu, X., Zhong, L., Meng, J., Wang, F., Zhang, J., Zhi, Y., Zeng, L., Tang, X. and Xu, J., 2018. A multi-medium chain modeling approach to estimate the cumulative effects of cadmium pollution on human health. Environ. Pollut. 239, 308-317. 
Nordberg, G.F., 2009. Historical perspectives on cadmium toxicology. Toxicol. Appl. Pharmacol. 238(3), 192-200.

Siegel, F.R., 2002. Environmental Geochemistry of Potentially Toxic Metals, pp. 77-101, Springer.

Carolin, C.F., Kumar, P.S., Saravanan, A., Joshiba, G.J. and Naushad, M., 2017. Efficient techniques for the removal of toxic heavy metals from aquatic environment: A review. J. Environ. Chem. Eng. 5(3), 2782-2799.

Flores-Cano, J.V., Leyva-Ramos, R., Mendoza-Barron, J., Guerrero-Coronado, R.M., Aragón-Piña, A. and Labrada-Delgado, G.J., 2013. Sorption mechanism of Cd(II) from water solution onto chicken eggshell. Appl. Surf. Sci. 276, 682-690.

Ahmad, M., Usman, A.R.A., Lee, S.S., Kim, S.-C., Joo, J.-H., Yang, J.E. and Ok, Y.S., 2012. Eggshell and coral wastes as low cost sorbents for the removal of $\mathrm{Pb}^{2+}, \mathrm{Cd}^{2+}$ and $\mathrm{Cu}^{2+}$ from aqueous solutions. J. Ind. Eng. Chem. Res. 18(1), 198-204.

Du, Y., Lian, F. and Zhu, L., 2011. Biosorption of divalent $\mathrm{Pb}, \mathrm{Cd}$ and $\mathrm{Zn}$ on aragonite and calcite mollusk shells. Environ. Pollut. 159(7), 1763-1768.

Hsu, T.-C., 2009. Experimental assessment of adsorption of $\mathrm{Cu}^{2+}$ and $\mathrm{Ni}^{2+}$ from aqueous solution by oyster shell powder. Journal of Hazardous Materials 171(1), 995-1000.

Shaheen, S.M., Eissa, F.I., Ghanem, K.M., Gamal El-Din, H.M. and Al Anany, F.S., 2013. Heavy metals removal from aqueous solutions and wastewaters by using various byproducts. J. Environ. Manage. 128, 514-521.

Zhou, X., Liu, W., Tian, C., Mo, S., Liu, X., Deng, H. and Lin, Z., 2018. Mussel-inspired functionalization of biological calcium carbonate for improving $\mathrm{Eu}(\mathrm{III})$ adsorption and the related mechanisms. Chem. Eng. J. 351, 816-824.

Feng, Q.L., Pu, G., Pei, Y., Cui, F.Z., Li, H.D. and Kim, T.N., 2000. Polymorph and morphology of calcium carbonate crystals induced by proteins extracted from mollusk shell. J. Cryst. Growth 216(1), 459-465.

Zhao, B., Zhang, J.-e., Yan, W., Kang, X., Cheng, C. and Ouyang, Y., 2016. Removal of cadmi um from aqueous solution using waste shells of golden apple snail. Desalin. Water Treat. 57(50), 23987-24003.

Hamester, M.R.R., Balzer, P.S. and Becker, D., 2012. Characterization of calcium carbonate obtained from oyster and mussel shells and incorporation in polypropylene. Mater. Res. 15, 204208.

Prieto, M., Cubillas, P. and Fernández-Gonzalez, Á., 2003. Uptake of dissolved Cd by biogenic and abiogenic aragonite: a comparison with sorption onto calcite. Geochim. Cosmochim. Acta 67(20), 3859-3869.

Tran, H.N., You, S.-J. and Chao, H.-P., 2016. Effect of pyrolysis temperatures and times on the adsorption of cadmium onto orange peel derived biochar. Waste Manage. Res. 34(2), 129 138.

Alidoust, D., Kawahigashi, M., Yoshizawa, S., Sumida, H. and Watanabe, M., 2015. Mechanism of cadmium biosorption from aqueous solutions using calcined oyster shells. J. Environ. Manage. 150, 103-110.

Lim, A.P. and Aris, A.Z., 2014. Continuous fixed-bed column study and adsorption modeling: Removal of cadmium (II) and lead (II) ions in aqueous solution by dead calcareous skeletons. Biochem. Eng. J. 87, 50-61.

Xiong, J., Qin, Y., Islam, E., Yue, M. and Wang, W., 2011. Phosphate removal from solution using powdered freshwater mussel shells. Desalination 276(1), 317-321.

Nan, Z., Shi, Z., Yan, B., Guo, R. and Hou, W., 2008. A novel morphology of aragonite and an abnormal polymorph transformation from calcite to aragonite with PAM and CTAB as additives. J. Colloid Interface Sci. 317(1), 77-82. 
Veneu, D.M., Schneider, C.L., de Mello Monte, M.B., Cunha, O.G.C. and Yokoyama, L., 2017. Cadmium removal by bioclastic granules (Lithothamnium calcareum): batch and fixed-bed column systems sorption studies. Environ. Technol., 1-12.

Sdiri, A., Higashi, T., Jamoussi, F. and Bouaziz, S., 2012. Effects of impurities on the removal of heavy metals by natural limestones in aqueous systems. J. Environ. Manage. 93(1), 245253.

Slimani, R., El Ouahabi, I., Abidi, F., El Haddad, M., Regti, A., Laamari, M.R., Antri, S.E. and Lazar, S., 2014. Calcined eggshells as a new biosorbent to remove basic dye from aqueous solutions: Thermodynamics, kinetics, isotherms and error analysis. J. Taiwan Inst. Chem. Eng. 45(4), 1578-1587.

El Haddad, M., 2016. Removal of Basic Fuchsin dye from water using mussel shell biomass waste as an adsorbent: Equilibrium, kinetics, and thermodynamics. J. Taibah Univ. Sci. 10(5), 664674.

Ismail, F.A. and Aris, A.Z., 2013. Experimental determination of $\mathrm{Cd}^{2+}$ adsorption mechanism on lowcost biological waste. Front. Environ. Sci. Eng. 7(3), 356-364.

Kuh, S.E. and Kim, D.S., 2000. Removal characteristics of cadmium ion by waste egg Shell. Environ. Technol. 21(8), 883-890.

Zhou, C., Gong, X., Zhang, W., Han, J., Guo, R. and Zhu, A., 2017. Uptake of Cd (II) Onto Raw Crab Shells: Isotherm, Kinetic, Adsorption Properties And Mechanisms. Water Environ. Res. 89(9), 817-826.

Köhler, S.J., Cubillas, P., Rodríguez-Blanco, J.D., Bauer, C. and Prieto, M., 2007. Removal of Cadmium from Wastewaters by Aragonite Shells and the Influence of Other Divalent Cations. Environ. Sci. Technol. 41(1), 112-118.

McBride, M.B.,1980. Chemisorption of $\mathrm{Cd}^{2+}$ on Calcite Surfaces. Soil Sci. Soc. Am. J. 44, $26-28$.

Saleh, M.E., El-Refaey, A.A. and Mahmoud, A.H., 2016. Effectiveness of Sunflower Seed Husk Biochar for Removing Copper Ions from Wastewater: a Comparative Study. Soil \& Water Research 11(1).

Tran, H.N., You, S.-J., Hosseini-Bandegharaei, A. and Chao, H.-P., 2017. Mistakes and inconsistencies regarding adsorption of contaminants from aqueous solutions: A critical review. Water Res. 120, 88-116.

Du, Y., Zhu, L. and Shan, G., 2012. Removal of $\mathrm{Cd}^{2+}$ from contaminated water by nano-sized aragonite mollusk shell and the competition of coexisting metal ions. J. Colloid Interface Sci. 367(1), 378-382.

Ferreira, G.M.D., Ferreira, G.M.D., Hespanhol, M.C., de Paula Rezende, J., dos Santos Pires, A.C., Gurgel, L.V.A. and da Silva, L.H.M., 2017. Adsorption of red azo dyes on multi-walled carbon nanotubes and activated carbon: A thermodynamic study. Colloids Surf. A 529, 531-540.

Cooney, D.O., 1998. Adsorption design for wastewater treatment, CRC press.

Baláž, M., Ficeriová, J. and Briančin, J., 2016. Influence of milling on the adsorption ability of eggshell waste. Chemosphere 146, 458-471.

Vilvanathan, S. and Shanthakumar, S., 2017. Column adsorption studies on nickel and cobalt removal from aqueous solution using native and biochar form of Tectona grandis. Environ. Prog. Sustain. Energy. 36(4), 1030-1038.

Chao, H.-P., Chang, C.-C. and Nieva, A., 2014. Biosorption of heavy metals on Citrus maxima peel, passion fruit shell, and sugarcane bagasse in a fixed-bed column. J. Ind. Eng. Chem. Res. 20(5), 3408-3414.

Zhang, T., Tu, Z., Lu, G., Duan, X., Yi, X., Guo, C. and Dang, Z., 2017. Removal of heavy metals from acid mine drainage using chicken eggshells in column mode. J. Environ. Manage. 188, $1-8$. 
Li, C. and Champagne, P., 2009. Fixed-bed column study for the removal of cadmium (II) and nickel (II) ions from aqueous solutions using peat and mollusk shells. J. Hazard. Mater. 171(1), 872-878.

Guo, H., Zhang, S., Kou, Z., Zhai, S., Ma, W. and Yang, Y., 2015. Removal of cadmium(II) from aqueous solutions by chemically modified maize straw. Carbohydr. Polym. 115, 177-185.

Li, Q., Csetenyi, L. and Gadd, G.M., 2014. Biomineralization of Metal Carbonates by Neurospora crassa. Environ. Sci. Technol. 48(24), 14409-14416.

Ghosh, P., 2009. Colloid and interface science, PHI Learning Pvt. Ltd.

Hill, C.G. and Root, T.W., 2014. Introduction to Chemical Engineering Kinetics and Reactor Design, pp. 152-188, John Wiley \& Sons.

Cubillas, P., Köhler, S., Prieto, M., Causserand, C. and Oelkers, E.H., 2005. How do mineral coatings affect dissolution rates? An experimental study of coupled $\mathrm{CaCO}_{3}$ dissolution- $\mathrm{CdCO}_{3}$ precipitation. Geochim. Cosmochim. Acta 69(23), 5459-5476.

Coelho, G.F., Gonçalves Jr, A.C., Tarley, C.R.T., Casarin, J., Nacke, H. and Francziskowski, M.A., 2014. Removal of metal ions $\mathrm{Cd}(\mathrm{II}), \mathrm{Pb}$ (II), and $\mathrm{Cr}$ (III) from water by the cashew nut shell Anacardium occidentale L. Ecol. Eng. 73, 514-525.

Tran, H.N. and Chao, H.-P., 2018. Adsorption and desorption of potentially toxic metals on modified biosorbents through new green grafting process. Environ. Sci. Pollut. Res. 25(13), 1280812820.

Ismail, F.A., Aris, A.Z. and Latif, P.A., 2014. Dynamic behaviour of $\mathrm{Cd}^{2+}$ adsorption in equilibrium batch studies by $\mathrm{CaCO}_{3}-$ rich Corbicula fluminea shell. Environ. Sci. Pollut. Res. 21(1), 344-354. 